\title{
Geochemical and U-Pb and Sm-Nd isotopic constraints on the evolution of the Paleoproterozoic Ylitornio nappe complex, northern Fennoscandia
}

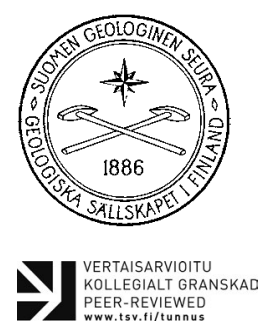

KOLLEGIALT GRAN
PEER-REVIEWED

\author{
Raimo Lahtinen ${ }^{{ }^{*}}$, Hannu Huhma ${ }^{\mathrm{I}}$, Laura S. Lauri ${ }^{2}$ \\ AND Mohammad SaYab ${ }^{\mathrm{I}}$ \\ ${ }^{1}$ Geological Survey of Finland, P.O. Box 96, FI-02151 Espoo, Finland \\ ${ }^{2}$ Geological Survey of Finland, P.O. Box 77, FI-96101 Rovaniemi, Finland
}

\section{Abstract}

The Ylitornio area in northern Finland is a typical example of a poorly outcropping, multiply deformed, complex Precambrian terrain. $\mathrm{U}-\mathrm{Pb}, \mathrm{Sm}-\mathrm{Nd}$ and geochemical data from metavolcanic, metasedimentary and plutonic rocks combined with structural data define the lithodemic units and tectonostratigraphy of the area.

The Mellajoki, Martimo, Hosiojoki, Kierovaara and Uusivirka suites form the Ylitornio nappe complex. Although main thrust stacking had occurred between 1.92$1.89 \mathrm{Ga}$, later reverse faulting probably continued until $1.78 \mathrm{Ga}$. The Väystäjä bimodal volcanic rocks (2.09-2.05 Ga) from the Martimo suite are plume-related EMORB-OIB rocks formed during a continent breakup. The Kaskimaa greywacke of the Martimo suite is inferred to represent sedimentation in a deepening rift basin in the continental margin. The coeval Hosiojoki felsic rocks with A-type affinity and the Kierovaara suite granites (2.00-1.98 Ga) represent dry melting of a dominantly 2.1-2.05 Ga contaminated mafic underplate, and hydrous melting of both the mafic underplate and a refractory lower crust of Archean age, respectively. The older rocks of the Uusivirka suite are early-collisional (1.92-1.91 Ga) and derived from poorly mixed local sources, whereas younger psammite-pelite associations (Ristivuoma) are syn-collisional (1.91$1.89 \mathrm{Ga}$ ) and derive from multiply recycled and thoroughly mixed sources. These rocks were deformed during continued collision with the development of foreland fold- and thrust belt.

Keywords: Svecofennian orogen, detrital zircon geochronology, Nd isotopes, sedimentary rocks, volcanic rocks, granitoids,

*Corresponding author (e-mail: raimo.lahtinen@gtk.fi)

Editorial handling: Alexander Slabunov (slabunov@krc.karelia.ru) 


\section{Introduction}

Polydeformed Precambrian cratonic shield areas typically lack vertical bedrock exposures hampering 3D field observations that are necessary to resolve the structural evolution and stratigraphic record of the bedrock (e.g., Sayab, 2009; Lahtinen et al., 2015a). Moreover, paleo-glaciation in Finland has mostly carved the landscape along with the deposition of Quaternary sedimentary cover, leaving limited windows for studying the bedrock. Consequently, stratigraphic and chronologic matching offers a tremendous challenge both in the lateral and vertical extent in such regions. The central part of northern Finland is a typical example of such a poorly outcropping, yet multiply deformed and metamorphosed complex. In general, the area may be divided into different parts where the migmatitic Paleoproterozoic Central Lapland Granitoid Complex (CLGC) occurs in the center, surrounded by Paleoproterozoic supracrustal belts in the north, east and south, and the Pajala shear zone in the west (Fig. 1).

Supracrustal belts in northern Finland have been divided into stratigraphic units and shieldwide correlations have been made using traditional stratigraphic names such as Sumi, Sariola, Jatuli, Ludicovi, and Kaleva (e.g., Meriläinen, 1980; Lehtonen et al., 1998; Ojakangas et al., 2001; Laajoki, 2005; Hanski et al., 2005; Hanski \& Melezhik, 2012; Ranta et al., 2015). According to the "Guidelines and Procedures for Naming Precambrian Geological Units in Finland" by Strand et al. (2010) the use of these traditional terms should be restricted to broad, informal discussion only. Recent detrital zircon geochronological data (e.g. Lahtinen et al., 2010, 2013, 2015b,c; Ranta et al., 2015) and an inferred new Paleoproterozoic plate boundary in northern Fennoscandia (Lahtinen et al., 2015b) also make the use of these terms problematic, especially in shield-wide correlations. The old stratigraphic division is further complicated by the recognition of ca. $1.99 \mathrm{Ga}$ A-type felsic tuffs/arkosites on both sides of the aulacogen (CLGC, $\mathrm{R}$ in Fig. 1) (Hanski et al.,
2005; Lahtinen et al., 2015b). Also the occurrence of orthoquartzites, earlier correlated with quartzites of Jatulian age (2.30-2.06 Ga), have a young maximum deposition age of $<1.92 \mathrm{Ga}$ (Lahtinen et al., 2015b). Previously defined lithostratigraphic units in northern Finland are informal, often discontinuous, and separated by regional-scale faults and thrust planes. Thus, many of these units were re-assigned as lithodemic units in the Bedrock of Finland-DigiKP database (see also Nironen, 2017). (Figure 1)

The lithostratigraphy of the Peräpohja Belt (PB; Fig. 1) is extensively studied and rather well known at least locally. Two major lithostratigraphic units, the Kivalo and Paakkola groups, have been proposed (Perttunen, 1985; Perttunen \& Hanski, 2003; Kyläkoski et al., 2012; Ranta et al., 2015). In these studies, both Väystäjä and Martimo were included in the PB but as discussed later, we prefer to separate them from the PB. Metamorphic grade (Perttunen \& Hanski, 2003; Hölttä \& Heilimo, 2017) varies from greenschist facies in the southwest (PB) to lower amphibolite facies more to the north (PB, Martimo, Väystäjä), and finally reaches upper amphibolite facies in the Hosiojoki and Mellajoki suites (Figs. 1 and 2; Bedrock of Finland-DigiKP). The Martimo-Mellajoki area (Fig. 1) manifests complex Paleoproterozoic tectonic evolution and five near-orthogonal deformation successions (D1 to D5) were identified (Lahtinen et al., 2015a; Sayab et al., 2017). The earliest deformation (D1) involved east-directed thin-skin thrusting. D2 deformation is characterized by N-S shortening with the development of pervasive E-W striking foliation and associated $\mathrm{F} 2$ upright folds with varying plunges due to the effects of later deformation events (D3, D4 and D5). These two (D1+D2) deformation events combined with low areal topography challenge the lithostratigraphic approach and mainly prevents its use. In the Pajala shear zone, rock units occur as blocks bounded by steeply oriented deformation zones, which complicates the interpretation even further.

In the study area (Fig. 2) thrust sheets are imbricated and stacked, and overprinted by 


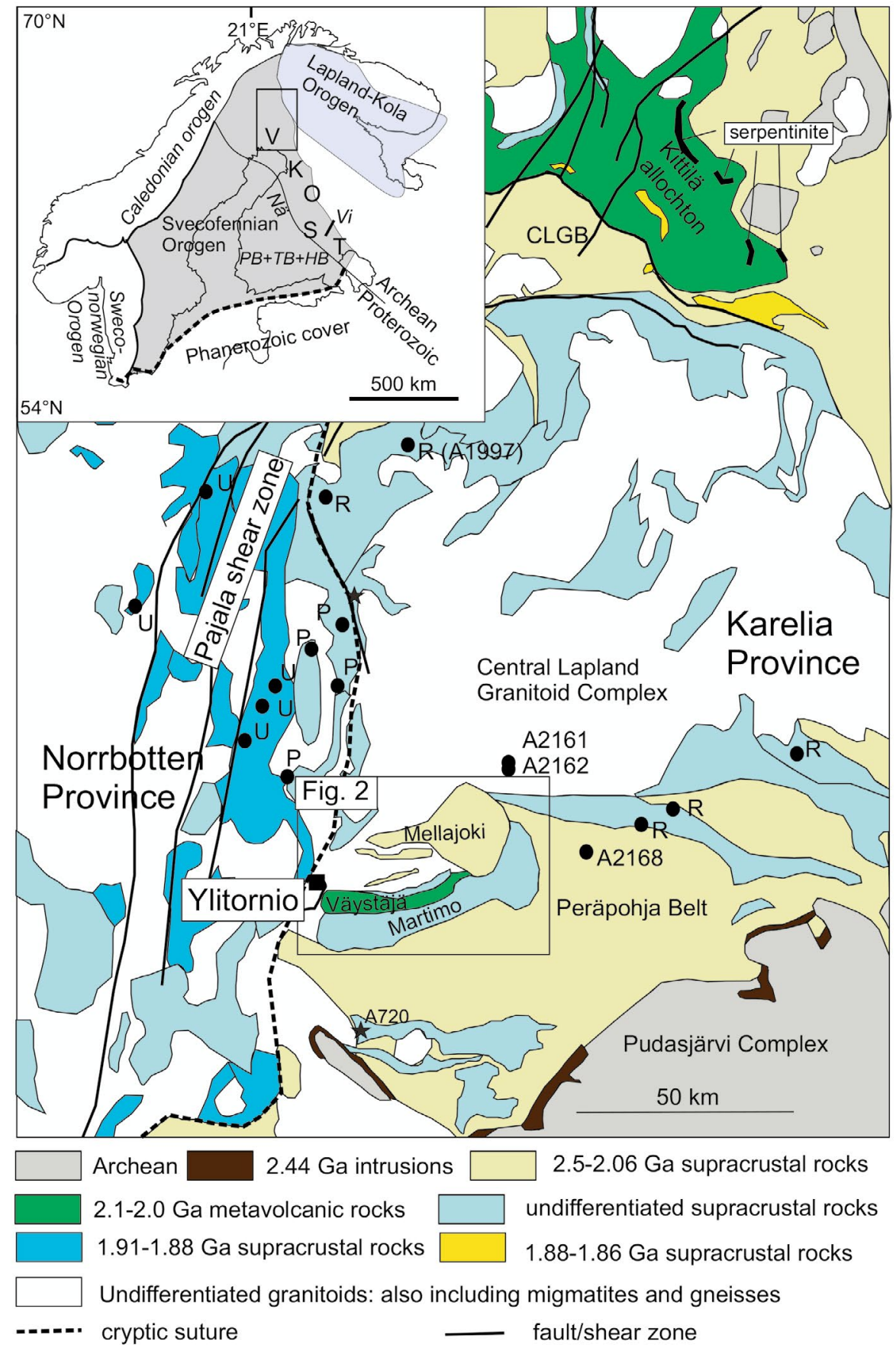

Figure 1. Simplified geological map of the study area modified from the Bedrock of Finland - DigiKP database. Sample points refer to samples included in this study (Data from Ranta et al., 2015 and Lahtinen et al., 2015b). A720 (star) will be discussed. CLGB = Central Lapland Greenstone Belt. R = Rovaniemi supersuite samples; P = Paskavaara suite samples; $U$ = Uusivirka suite samples. Inset figure shows the location of the study area in the Fennoscandian shield. $V=$ Väystäjä; $K=$ Kiiminki; $O=$ Otanmäki; $S=$ Siilinjärvi; $T=$ Tohmajärvi; $V i=$ Viinijärvi; $N a ̈$ = Näläntöjärvi; $P B+T B+H B=$ Pirkanmaa Belt occurs in the middle and Tampere (TB) and Häme (HB) belts occur north and south of it, respectively. 
a sequence of later deformation events (Lahtinen et al., 2015a). The eastern part of the study area has been a focus of detailed studies due to the recent discovery of the extensive gold-mineralized Rompas zone (Fig. 2; Vanhanen et al., 2015; Molnár et al., 2016). Ranta et al. (2015) have studied the metasedimentary and igneous rocks from the study area and the surroundings using zircon $\mathrm{U}-\mathrm{Pb}$ dating and $\mathrm{Sm}-\mathrm{Nd}$ analysis. Lahtinen et al. (2015b) published $1130 \mathrm{U}-\mathrm{Pb}$ analyses on zircons from 25 samples across the Pajala shear zone.

In addition to existing data, new $\mathrm{U}-\mathrm{Pb}$ data from four metasedimentary rock and five granitoid samples, and Sm-Nd and geochemical data from metavolcanic, metasedimentary and plutonic rocks are presented. Instead of a lithostratigraphic approach, we will apply lithodemic units and tectonostratigraphy to untangle the evolution of this polyphase deformed and metamorphosed area. We have used geochemisty, and U-Pb and $\mathrm{Sm}-\mathrm{Nd}$ isotope data to define the units and the tectonic setting of rocks within units. By combining multiple datasets, we propose a framework of a fold-andthrust system, comprising the Mellajoki, Martimo, Hosiojoki, Kierovaara and Uusivirka suites, forming a tectonostratigraphic unit, the Ylitornio nappe complex.

\section{Regional geology and samples}

The main Paleoproterozoic orogenic evolution of Fennoscandia formed the Lapland-Kola orogen (1.94-1.86 Ga; Daly et al, 2006) and the composite Svecofennian orogen (Fig. 1 inset), further divided into the Lapland-Savo, Fennian, Svecobaltic and Nordic orogens (1.92-1.79 Ga; Lahtinen et al, 2005; 2009). Lahtinen et al. (2015a) proposed a D1 to D5 deformation scheme for northern Fennoscandia, which can be readily reconciled with the tectonic evolution of the composite Svecofennian orogen. The CLGC, which occurs in the northern part of the Svecofennian orogen, inferred to represent a concealed aulacogen that has a pre-collisional (>1.92 Ga) history of multiple rifting and depositional stages (Lahtinen et al., 2015b). The western boundary of the CLGC is marked by the approximately $\mathrm{N}-\mathrm{S}$ trending Paleoproterozoic Pajala shear zone (Kärki et al., 1993; Baltic-Bothnian megashear by Berthelsen \& Marker, 1986), which is inferred to coincide with a cryptic suture separating two colliding Archean continental units (Norrbotten and Karelia) (Lahtinen et al., 2015b). The occurrence of a plate boundary is also favored based on different anisotropic structures between the Norrbotten and Karelia Archean mantle lithospheres (Vecsey et al., 2014). The Pajala shear zone proper is mainly a younger overprinting structure which was multiply reactivated by both lateral and vertical movements.

The Karelia province includes the Archean Pudasjärvi complex (Fig. 1; Mutanen and Huhma, 2003), intruded by $2.44 \mathrm{Ga}$ layered intrusions (Iljina \& Hanski, 2005; Lauri et al., 2012). The Paleoproterozoic supracrustal rocks of the Peräpohja Belt were deposited in both continental and marine environments on top of the Pudasjärvi complex. The Central Lapland Greenstone Belt (CLGB), north of the CLGC, shows similarities in lithology and stratigraphy with the Peräpohja Belt, favoring a common history of the supracrustal belts between 2.45-2.05 Ga (Lehtonen et al. 1998; Hanski \& Huhma, 2005). The formation of a failed arm of a triple junction (aulacogen) resulted from continental breakup at 2.1-2.05 Ga along the present western margin of the Karelia province. The CLGC represents the exhumed root zone of this aulacogen (Lahtinen et al., 2015b). In the Norrbotten province, west of the cryptic suture (Fig. 1), the bedrock is dominated by medium to high-grade, commonly migmatitic, metasedimentary rocks with subordinate metavolcanic rocks (e.g. Bergman et al., 2001). Plutonic rocks include felsic to mafic intrusive rocks representing three age groups: ca. $1.89-1.88 \mathrm{Ga}$, ca. 1.88-1.87 Ga and ca. 1.81-1.78 Ga (Bergman et al., 2001). The study area is marked on the map (Fig. 1) and shown in Fig. 2 along with sample locations. Some reference samples from previous 


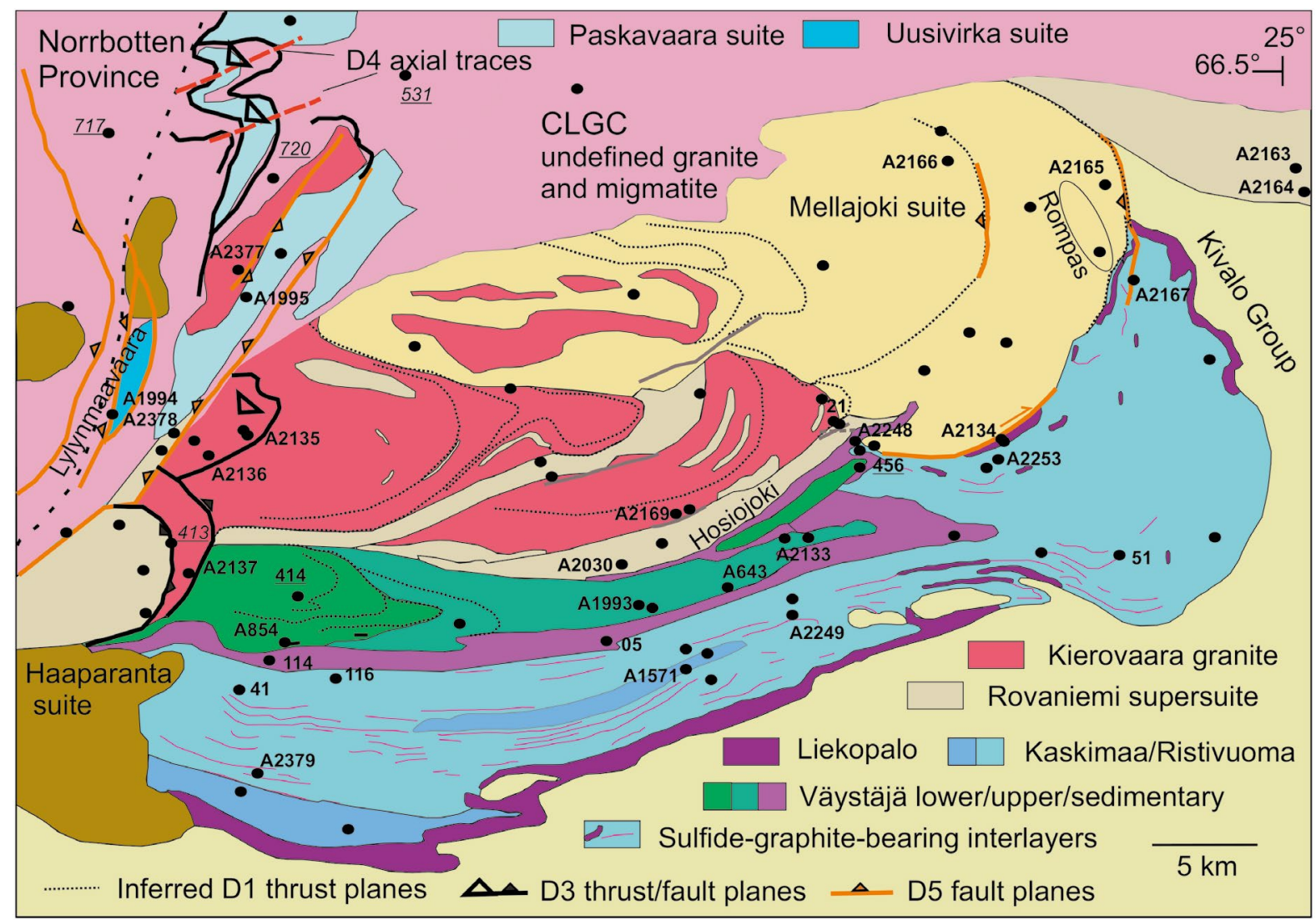

Figure 2. Simplified geological map of the study area modified from Bedrock of Finland-DigiKP with sample points used in geochemical diagrams (Electronic Appendix A). Numbers refer to samples in Table 1 and they are discussed in the text, except numbers in italics, which only are found in Electronic Appendix A.

studies are shown in Fig. 1. The ca. 3- to 4-km-thick Kivalo group (2.5-2.06 Ga) of the Peräpohja Belt (Fig. 2) comprises abundant orthoquartzites and arenites, conglomerates, dolomites and basalts, and is intruded by mafic sills and dykes (Perttunen \& Hanski, 2003). Only the quartzite sample A2168 (Fig. 1; Ranta et al., 2015) from the Kivalo group is briefly discussed here. Based on orthoquartzite samples A2166 (Mellajoki suite) and A2168 (Kivalo group) Ranta et al. (2015) suggested that the Mellajoki suite (Fig. 2.) could be correlated with the Palokivalo formation of the Kivalo group.

The Kaskimaa greywacke of the Martimo suite (Bedrock of Finland-DigiKP) is divided into three lithodemic units; Liekopalo, Kaskimaa and Ristivuoma (Fig. 2). The Liekopalo paraschists and the Kaskimaa greywackes are included in the
Martimo suite, whereas the Ristivuoma metasedimentary rocks are part of the Uusivirka suite. The graphite- and Fe-sulfide-bearing Liekopalo paraschists with quartzite interlayers (Lahtinen et al., 2015a) occur in close association with the quartzites of the Kivalo group in the south and east and with the quartzites of the Mellajoki suite in the north (Fig. 2). The contact between the Liekopalo and Mellajoki units is locally a fault breccia (A2134 in Fig. 2) showing apparent dextral strike-slip movement. Quartzitic breccia matrix A2134 (Fig. 3a) and quartzite-graphite schist pair located $40 \mathrm{~m} \mathrm{SE}$ from the fault contact have been sampled. Sample A1571 (Fig. 2; Hanski et al., 2005; Lahtinen et al., 2015b) is from the type location of the Kaskimaa greywackes, which comprise a thick sequence of turbidites with interlayered pelites. 

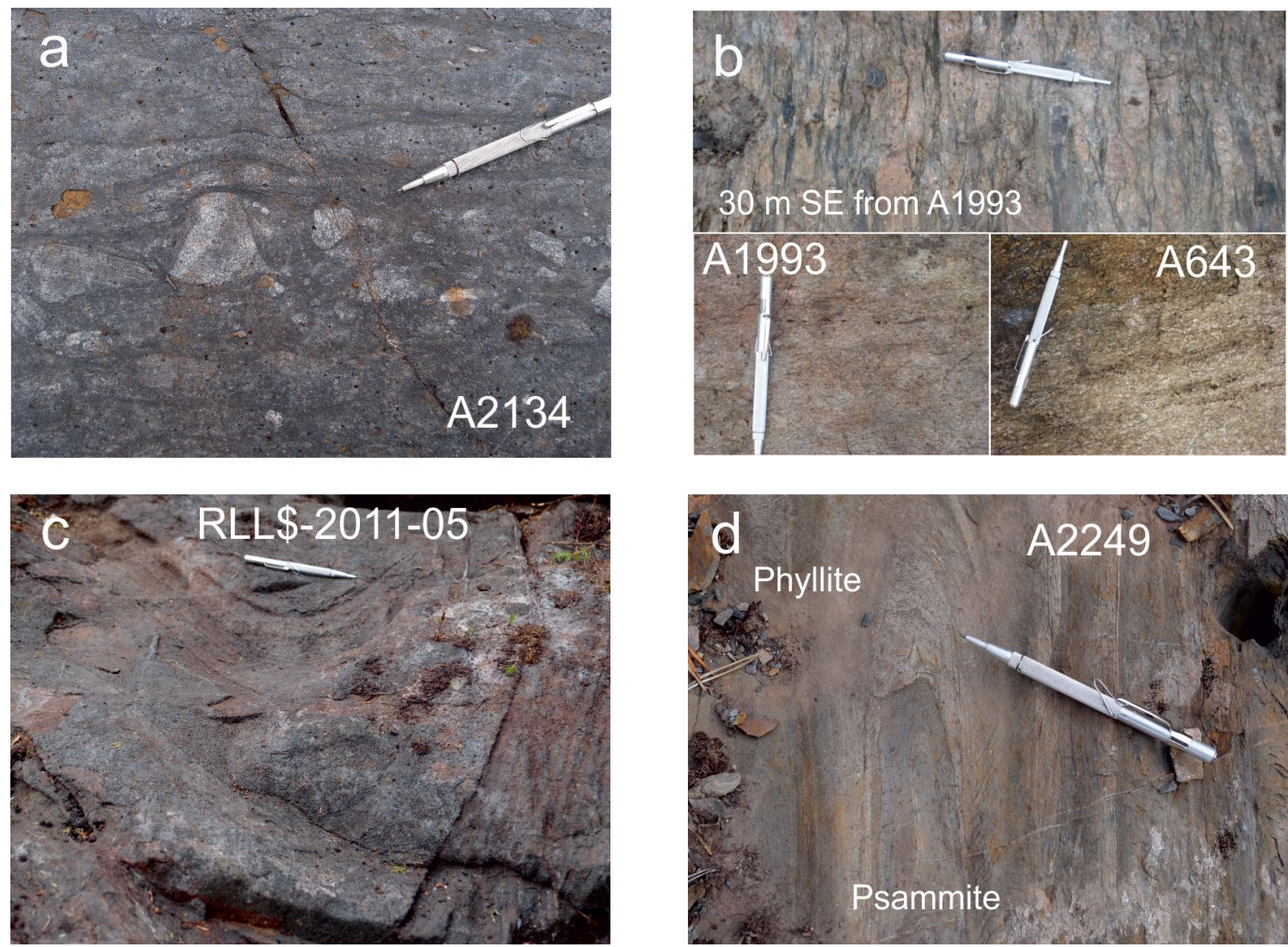

Figure 3. Selected sampled outcrops. The length of the magnet pen is $13 \mathrm{~cm}$. a = Fault breccia with graphite-rich quartzitic matrix (A2134, Liekopalo); b = Väystäjä felsic porphyry (A643; $2050 \pm 8$ Ma, Perttunen and Vaasjoki, 2001), A1993 = Väystäjä volcano-sedimentary rock (all zircons ca. 2.05 Ga Ma; Lahtinen et al., 2015b) as interlayer in conglomerate; $c=$ mafic volcanic rock interlayer (RLL\$-2011-05) in the Väystäjä metasedimentary rock; $d$ = Ristivuoma metasedimentary rock (A2249).

The Ristivuoma metasedimentary rocks are the dominant rock type in the study area (Fig. 2) and they vary from psammites to thinly layered phyllites and paraschists. Samples A2248, A2249 (Fig. 3) and A2253 were collected from psammitic layers.

The Väystäjä supracrustal rocks are separated into three units. The tentative division into the lower and upper Väystäjä mafic volcanic rock units is assumed based on inferred thrust planes and crosscutting dykes. Dyke A854 (Fig. 2) has an age of $2084 \pm 11 \mathrm{Ma}$ (Huhma et al., 2018), which gives the upper age limit for the surrounding volcanic rocks that are classified as the lower Väystäjä mafic volcanic rocks. The upper Väystäjä mafic volcanic rocks are associated with minor sedimentary rocks
(Perttunen \& Hanski, 2003), including dolomites with a normal $\delta^{13} \mathrm{C}$ composition, favoring $<2.06$ Ga depositional age for them (Karhu, 2005). An association of felsic porphyries (A643; $2050 \pm 8 \mathrm{Ma}$, Perttunen \& Vaasjoki, 2001), intraformational conglomerate (Fig. 3) and volcano-sedimentary rocks (A1993, all zircons ca. 2.05 Ga Ma; Lahtinen et al., 2015b) are used to bracket the upper Väystäjä volcanic rocks at 2.09-2.05 Ga. Pyrrhotite-rich, fine-grained phyllites and paraschists dominate in the Väystäjä sedimentary unit (Fig. 2). The original lamination cannot be observed and typical layer thickness is $1-5 \mathrm{~cm}$. Thicker, more psammitic layers are rare. Apart from metamorphic recrystallization, compositional differences in adjacent layers are 

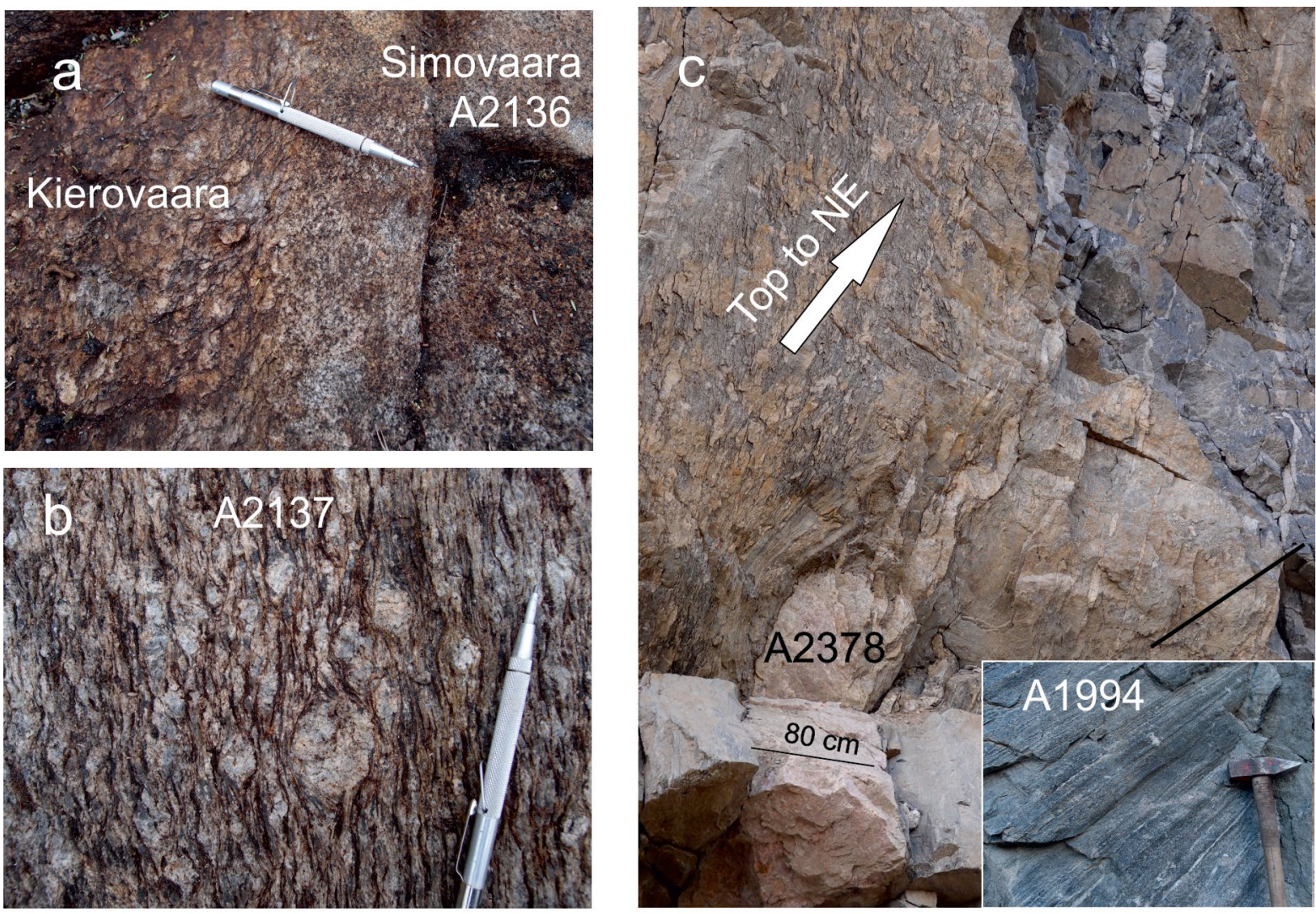

Figure 4. Selected sampled outcrops. The length of the magnet pen is $13 \mathrm{~cm}$ and the hammer head is $16 \mathrm{~cm}$ long. $a=$ Simovaara monzonite (A2136) crosscutting Kierovaara-type granite; b = Kierovaara-type granite (A2137); $c=$ Lylynmaanvaara-type hornblende-bearing paragneiss (sample A1994) is crosscut by granite (sample A2378) and both are deformed by top to NE reverse faulting (D5, Lahtinen et al., 2015b).

observed and one sample pair of pelite-phyllite has been sampled from location 114 (Fig. 2). Mafic volcanic rock interlayers are also found, e.g. from location 05 (Figs. 2 and 3).

The Hosiojoki quartz-feldspar gneiss (A2030, zircons ca. $1.99 \mathrm{Ga}$; Lahtinen et al., 2015b) is locally characterized by phenocryst-like bluish quartz, but due to strong metamorphic overprint no clear evidence of volcanic origin is observed. Occurrences of the Hosiojoki suite, based on geochemistry, are shown in Fig. 2 and they are part of the bimodal Rovaniemi supersuite (Hanski et al., 2005; Lahtinen et al., 2015b). The Kierovaara granite suite (A2169 in Fig. 2, $1989 \pm 6 \mathrm{Ma}$ ) is a new plutonic suite dated and defined by Ranta et al. (2015). Typically, the Kierovaara granites are red or white in color, K-feldspar-porphyritic and strongly flattened, showing augen gneiss texture. Large paraschist and meta-arkose-quartzite enclaves occur within granite (Perttunen \& Hanski, 2003). New samples A2135, A2137 (Fig. 4) and A2378 from the Kierovaara suite were collected (Fig. 2) in addition to a sample from the Simovaara monzonite (A2136, Figs. 2 and 4) crosscutting the Kierovaara granite.

The Paskavaara suite is composed of commonly migmatitic quartz-feldspar gneisses that locally show heavy mineral laminae and $\mathrm{Cr}$-bearing minerals (Lahtinen et al., 2015b). The Paskavaara suite in Fig. 2 is included in the Norrbotten province but correlation of sample A1995 to the Mellajoki suite in the Karelia province is also possible. The Uusivirka suite comprises hornblende- 
bearing metasedimentary rocks (sample A1994 in Fig. 2), meta-arkoses, orthoquartzites and pelitic paraschists with maximum depositional ages of 1.92-1.91 Ga (Lahtinen et al., 2015b).

The age of D1 in the study area is $1.91-1.89 \mathrm{Ga}$ based on maximum deposition ages of sedimentary rocks and crosscutting 1.89-1.88 Ga D2 granitoids (Lahtinen et al., 2015a). Two dykes A2133 and A2379 were sampled to date more closely the D2 and D3 events, respectively, but unfortunately no zircons were found. Syn-tectonic (D5, Lahtinen et al., 2015a) aplite granites crosscut hornblendebiotite paragneiss A1994 and one sample (A2378, Fig. 4) was taken to date the D5 deformation event. The Haaparanta (Haparanda in Sweden) suite granitoids (1885-1880 Ma, Fig. 1) and undefined granites (typically ca. $1.80-1.77 \mathrm{Ga}$ ) are stitching plutons, as they crosscut older $(>1.89 \mathrm{Ga})$ units in both Norrbotten and Karelia provinces. Data for granites A2161-A2164 from Ranta et al. (2015) and additional geochemical data of the undefined granites (Figs. 1 and 2) will be discussed.

\section{Analytical methods}

Major elements and $\mathrm{Ba}, \mathrm{Cr}, \mathrm{Cu}, \mathrm{Ni}, \mathrm{S}, \mathrm{Sr}, \mathrm{V}, \mathrm{Y}$, $\mathrm{Zn}$, and $\mathrm{Zr}$ were determined by XRF from pressed briquettes, and non carbonate $\mathrm{C}$ and $\mathrm{CO}_{2}$ by Leco CR-12 carbon analyzer. REE, Co, Nb, Hf, Rb, Sc, $\mathrm{Ta}$, Th and U were determined by ICP-MS from solution combining those after dissolution of the sample $(0.2 \mathrm{~g})$ with hydrofluoric acid-perchloric acid and a lithium metaborate/sodium perborate fusion of the insoluble residue (see Rasilainen et al., 2007 for details). All analyses were done in the Labtium Oy laboratories.

Lahtinen \& Huhma (1997) described the analytical techniques for $\mathrm{Sm}-\mathrm{Nd}$ data and the longterm average ${ }^{143} \mathrm{Nd} /{ }^{144} \mathrm{Nd}$ for the La Jolla standard is $0.511851 \pm 0.000008$ (standard deviation for 69 measurements during 2012). Based on duplicate analyses, the error in ${ }^{147} \mathrm{Sm} /{ }^{144} \mathrm{Nd}$ is estimated to be 0.4 .
$\mathrm{U}-\mathrm{Pb}$ analyses were performed using a $\mathrm{Nu}$ Plasma HR multicollector ICP-MS combined with a New Wave UP193 or Photon Machine Analyte G2 (for A2100) laser microprobe. Standard zircons GJ-1 (609 $\pm 1 \mathrm{Ma})$ and in-house standards A382 $(1977 \pm 2 \mathrm{Ma})$ or A1772 (2712 $\pm 1 \mathrm{Ma})$ were used for calibration (Huhma et al., 2012). Age calculations and related diagrams were made using Isoplot/ Exv 2.49 (Ludwig, 2003).

\section{Results}

Geochemical and $\mathrm{U}-\mathrm{Pb}$ data are in Electronic Appendices A and B, respectively. Sm-Nd data are in Table 1 and presented in Fig. 6.

\subsection{Metasediments, metavolcanic rocks and dykes}

The Ristivuoma psammite samples A2248, 2249 and A2253 have 35\%, 23\% and 50\% of Archean zircons, respectively (Electronic Appendix B). There are only few zircons in the age range 2.6-2.2 $\mathrm{Ga}$ and the $<2.2 \mathrm{Ga}$ zircons are shown in Fig. 5 with psammite A2167 (Ranta et al., 2015) and a compilation of the Uusivirka metasedimentary rocks (Fig. 1) shown as a comparison. The Ristivuoma samples are characterized by $1.93-1.90$ Ga zircons and the maximum deposition age varies from $1.90 \mathrm{Ga}$ (A2248 and A2249) to $1.91 \mathrm{Ga}$ (A2253 and A2167). Quartzitic fault breccia matrix sample A2134 comprises only Archean detrital zircons with ages between $2.6 \mathrm{Ga}$ and $3.5 \mathrm{Ga}$ (Electronic Appendix B). Noticeable feature is that $56 \%$ of zircons have ages between 2.6-2.7 Ga.

Sm-Nd data of sample A2134 (Table 1 and Fig. 6) correlate well with the absence of Proterozoic zircons. Data from the Ristivuoma sedimentary rocks show the mixing of Archean and Paleoproterozoic source material in both Sm-Nd analyses and detrital zircon ages. Sample RLL\$2013-51 shows LREE-depletion (see Lahtinen et al., 2013) and simple age calculation with a sample 
Table 1. Sm-Nd isotope data from the study area.

\begin{tabular}{|c|c|c|c|c|c|c|c|c|c|c|c|c|c|}
\hline \multirow[t]{2}{*}{ Sample } & \multirow[t]{2}{*}{ Rock type } & \multirow[t]{2}{*}{ Unit } & \multicolumn{2}{|c|}{ ETRS-TM35FIN } & \multirow{2}{*}{$\begin{array}{l}\text { Sm } \\
\mathrm{ppm}\end{array}$} & \multirow{2}{*}{$\begin{array}{l}\mathrm{Nd} \\
\mathrm{ppm}\end{array}$} & \multirow{2}{*}{$\begin{array}{l}{ }^{147} \mathrm{Sm} / \\
{ }^{144} \mathrm{Nd}\end{array}$} & \multirow{2}{*}{$\begin{array}{l}{ }^{143} \mathrm{Nd} / \\
{ }^{144} \mathrm{Nd}\end{array}$} & \multirow{2}{*}{$\begin{array}{l}2 \text { sigma } \\
\text { error }\end{array}$} & \multirow{2}{*}{$\begin{array}{l}\mathrm{T}^{1} \\
\mathrm{Ma}\end{array}$} & \multirow[t]{2}{*}{$\mathrm{e}_{\mathrm{Nd}}(\mathrm{T})$} & \multirow{2}{*}{$\begin{array}{l}\mathrm{T}_{\mathrm{DM}} \\
\mathrm{Ma}\end{array}$} & \multirow[t]{2}{*}{ ref. } \\
\hline & & & $\mathrm{x}$ & $\mathrm{y}$ & & & & & & & & & \\
\hline \multicolumn{14}{|c|}{ Volcanic rocks and dikes } \\
\hline & Mafic volcanic & & & & & & & & & & & & \\
\hline \multirow[t]{2}{*}{ RLL\$-2011-05.1 } & rock & Väystäjä & 378140 & 7351885 & 3.25 & 11.70 & 0.1679 & 0.512143 & 0.000012 & 2050 & -2.2 & & \\
\hline & Mafic volcanic & & & & & & & & & & & & \\
\hline \multirow[t]{2}{*}{ RLL\$-2011-21.1 } & rock & Hosiojoki? & 388797 & 7362006 & 5.00 & 19.18 & 0.1576 & 0.512005 & 0.000010 & 2000 & -2.4 & & \\
\hline & Mafic volcanic & & & & & & & & & & & & \\
\hline N93001414 & rock & Väystäjä & 363282 & 7354194 & 2.45 & 8.27 & 0.1794 & 0.512481 & 0.000010 & 2050 & 1.4 & & \\
\hline N93001456 & Mafic pillow lava & Väystäjä & 390072 & 7360671 & 3.99 & 12.09 & 0.1995 & 0.512739 & 0.000011 & 2050 & 1.2 & & \\
\hline A643 & Felsic porphyry & Väystäjä & 383612 & 7354370 & 17.25 & 84.21 & 0.1238 & 0.511665 & 0.000012 & 2050 & 0.1 & 2335 & \\
\hline & Volcano- & & & & & & & & & & & & \\
\hline A1993 & sedimentary rock & Väystäjä & 379441 & 7353554 & 13.40 & 66.09 & 0.1226 & 0.511700 & 0.000010 & 2050 & 1.2 & 2245 & 1 \\
\hline & Q-F gneiss/Volc.- & & & & & & & & & & & & \\
\hline A2030 & sed.? & Hosiojoki & 378736 & 7355470 & 12.00 & 61.22 & 0.1185 & 0.511544 & 0.000010 & 2000 & -1.3 & 2400 & 1 \\
\hline A2133 & Intermediate dyke & Väystäjä & 386219 & 7356759 & 8.03 & 34.19 & 0.1420 & 0.511976 & 0.000010 & 1880 & 0.2 & 2271 & \\
\hline Sedimentary rock & & & & & & & & & & & & & \\
\hline A1571 & Metagreywacke & Kaskimaa & 381729 & 7350557 & 2.82 & 12.30 & 0.1384 & 0.511801 & 0.000010 & 1900 & -2.2 & 2521 & 1,2 \\
\hline & Hornblende & & & & & & & & & & & & \\
\hline A1994 & gneiss & Uusivirka & 354599 & 7362562 & 4.20 & 18.58 & 0.1366 & 0.511786 & 0.000010 & 1900 & -2.0 & 2490 & 1 \\
\hline A2134 & Quartzite breccia & Mellajoki & 396254 & 7361399 & 0.49 & 2.27 & 0.1314 & 0.511365 & 0.000010 & 1900 & -9.0 & 3142 & \\
\hline A2165\#2 & Paragneiss & Mellajoki & 401600 & 7373480 & 10.49 & 63.94 & 0.0992 & 0.510996 & 0.000010 & 1900 & -8.4 & 2730 & 3 \\
\hline A2166 & Quartzite & Mellajoki & 394071 & 7374506 & 0.54 & 3.03 & 0.1081 & 0.510982 & 0.000014 & 1900 & -10.8 & 2990 & 3 \\
\hline A2167 & Psammite & Ristivuoma & 402871 & 7368972 & 5.57 & 28.81 & 0.1168 & 0.511499 & 0.000011 & 1900 & -2.8 & 2429 & 3 \\
\hline A2168 & Quartzite & Kivalo & 420831 & 7366509 & 1.07 & 5.59 & 0.1156 & 0.511052 & 0.000016 & 1900 & -11.3 & 3116 & 3 \\
\hline A2248 & Psammite & Ristivuoma & 389935 & 7360995 & 4.34 & 23.14 & 0.1135 & 0.511459 & 0.000015 & 1900 & -2.8 & 2408 & \\
\hline A2249 & Phyllite & Ristivuoma & 386743 & 7353043 & 4.47 & 22.33 & 0.1209 & 0.511543 & 0.000015 & 1900 & -2.9 & 2465 & \\
\hline A2249 & Psammite & Ristivuoma & 386743 & 7353043 & 3.38 & 17.36 & 0.1175 & 0.511500 & 0.000015 & 1900 & -3.0 & 2428 & \\
\hline A2249 \#2 & Psammite & Ristivuoma & 386743 & 7353043 & 3.15 & 16.64 & 0.1145 & 0.511510 & 0.000020 & 1900 & -2.0 & 2354 & \\
\hline A2253 & Psammite & Ristivuoma & 396531 & 7360452 & 3.02 & 15.85 & 0.1152 & 0.511420 & 0.000015 & 1900 & -4.0 & 2521 & \\
\hline RLL\$-2012- & & & & & & & & & & & & & \\
\hline 114.1 & Pelite & Väystäjä & 362043 & 7350952 & 2.22 & 8.72 & 0.1542 & 0.512104 & 0.000010 & 1900 & -0.1 & 2414 & \\
\hline RLL\$-2012- & & & & & & & & & & & & & \\
\hline 114.2 & Phyllite & Väystäjä & 362043 & 7350952 & 5.98 & 32.78 & 0.1103 & 0.511489 & 0.000010 & 1900 & -1.4 & 2288 & \\
\hline RLL\$-2012-116 & Psammite & Ristivuoma & 365136 & 7350051 & 2.80 & 13.90 & 0.1219 & 0.511488 & 0.000010 & 1900 & -4.3 & 2589 & \\
\hline RLL\$-2013-41 & Phyllite & Ristivuoma & 360613 & 7349474 & 5.61 & 29.08 & 0.1167 & 0.511496 & 0.000015 & 1900 & -2.8 & 2429 & \\
\hline RLL\$-2013-51 & Psammite & Ristivuoma & 402300 & 7356005 & 1.93 & 7.02 & 0.1664 & 0.511731 & 0.000015 & 1900 & -10.4 & 4549 & \\
\hline Plutonic rocks & & & & & & & & & & & & & \\
\hline A2135 & Porphyritic granite & Kierovaara & 361084 & 7361512 & 1.25 & 6.23 & 0.1216 & 0.511233 & 0.000014 & 1995 & -8.3 & 3017 & \\
\hline A2136 & Monzonite & Simovaara & 359259 & 7360604 & 11.57 & 63.70 & 0.1098 & 0.511437 & 0.000010 & 1800 & -3.4 & 2354 & \\
\hline & Porphyritic granite & & & & & & & & & & & & \\
\hline A2137 & (mylonitic) & Kierovaara & 358188 & 7355070 & 4.40 & 25.65 & 0.1037 & 0.511200 & 0.000010 & 2008 & -4.2 & 2556 & \\
\hline & & Undefined & & & & & & & & & & & \\
\hline A2161 & Granite & CLGC & 406321 & 7381161 & 2.80 & 20.69 & 0.0819 & 0.510966 & 0.000010 & 1775 & -6.6 & 2400 & 3 \\
\hline & Granite & Undefined & & & & & & & & & & & \\
\hline A2162 & (leucosome) & CLGC & 406143 & 7380007 & 3.57 & 14.41 & 0.1496 & 0.511650 & 0.000018 & 1793 & -8.5 & 3386 & 3 \\
\hline & Granite & Undefined & & & & & & & & & & & \\
\hline A2163 & (tourmaline, dyke) & CLGC & 410530 & 7374114 & 2.01 & 5.40 & 0.2254 & 0.512397 & 0.000011 & 1780 & -11.4 & & 3 \\
\hline & Granite & Undefined & & & & & & & & & & & \\
\hline A2164 & (tourmaline) & CLGC & 410966 & 7373150 & 0.84 & 1.93 & 0.2638 & 0.512847 & 0.000031 & 1780 & -11.4 & & 3 \\
\hline A2169 & Porphyritic granite & Kierovaara & 381295 & 7357823 & 4.78 & 30.46 & 0.0948 & 0.511106 & 0.000010 & 1989 & -3.9 & 2483 & 3 \\
\hline RLL\$-2012-94 & Monzonite & Simovaara & 358645 & 7360843 & 8.75 & 48.61 & 0.1088 & 0.511460 & 0.000010 & 1800 & -2.7 & 2297 & \\
\hline
\end{tabular}

$\mathrm{T}_{\mathrm{DM}}$ calculated according to DePaolo (1981). Overstriked samples show LREE depletion (see text).

${ }^{1}$ Ages for magmatic rocks are measured or inferred. Ages for sedimentary rocks are set as $1.9 \mathrm{Ga}$ for comparison purposes only.

References: ref. 1 - Lahtinen et al., 2015; 2 - Hanski et al., 2005; 3 - Ranta et al., 2015. 


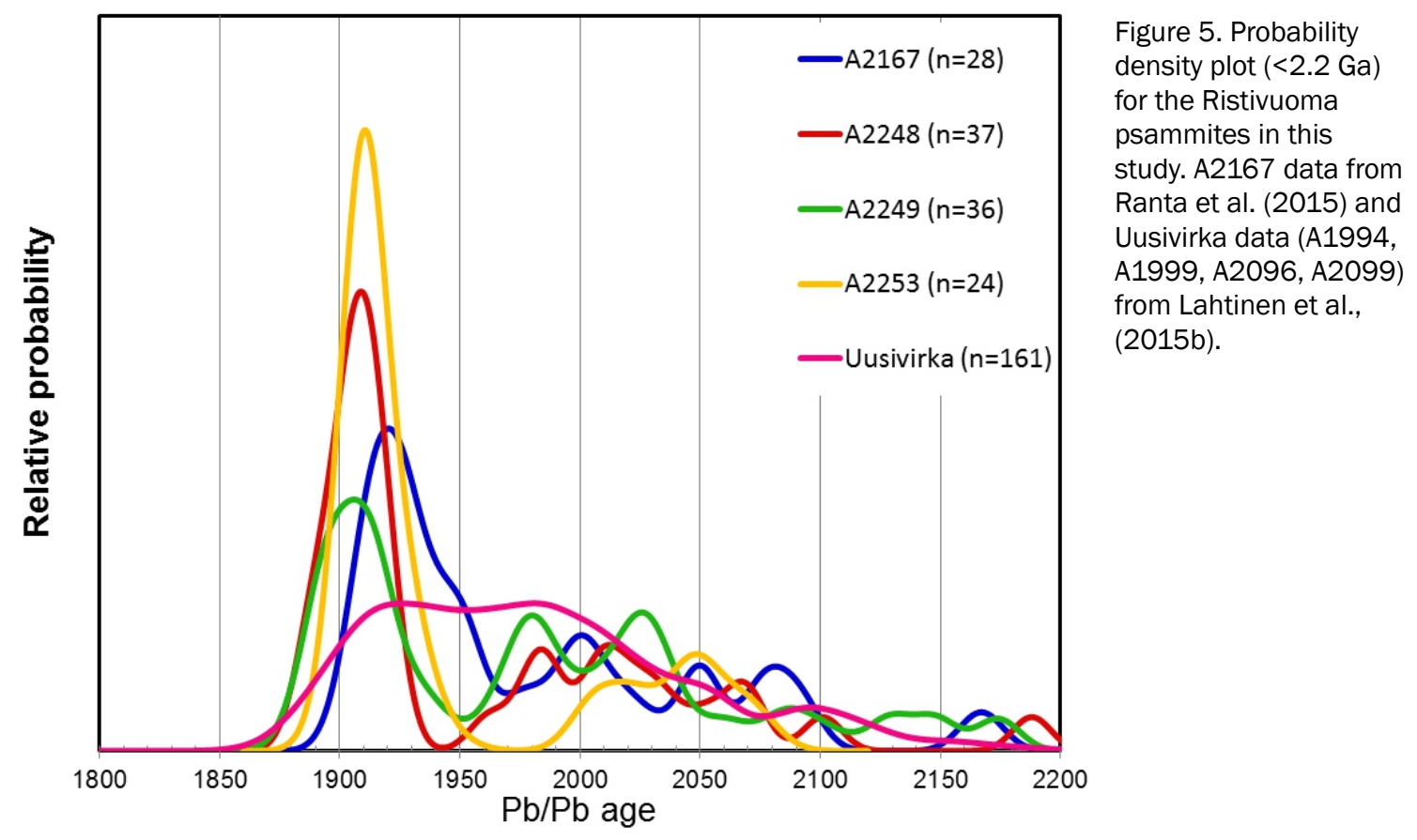

of "normal" REE trend (like A2167 or RLL\$2013-41) suggests an age of ca. $700 \mathrm{Ma}$ for the LREE depletion. The Väystäjä metasedimentary samples RLL\$-2011-114.1/2 show higher $\varepsilon_{\mathrm{Nd}}$ values compared to other metasedimentary rocks, indicating a more juvenile source.

\subsection{Plutonic rocks}

Samples A2135, A2137 and A2377 from the Kierovaara granite suite show U-Pb ages of $1995 \pm 10$ Ma, 2008 $\pm 7 \mathrm{Ma}$ and $1990 \pm 3 \mathrm{Ma}$, respectively (Electronic Appendix B and Figs. 7a,c,d). One Archean zircon core was analyzed from sample A2135. Simovaara monzonite sample A2136 has an age of $1800 \pm 11 \mathrm{Ma}$ (Fig. $7 \mathrm{~b}$ ). All these ages are interpreted as ages of magmatic crystallization. Sample A2378 was collected from a granite that crosscuts hornblende-bearing Lylynmaanvaara paragneiss (sample A1994) with the maximum depositional age of $1.91 \mathrm{Ga}$ (Lahtinen et al., 2015b). Nine of eleven dated zircons are $>1.91 \mathrm{Ga}$ in age and seven zircons give a concordia age of $1985 \pm 5$
Ma (Electronic Appendix B and Fig. 7e). These xenocrystic zircons are typically slightly rounded (Fig. 7f) either due to sedimentary abrasion and/or interaction with the magma. Two shabby zircons (7a and $11 \mathrm{a}$ ) give $\mathrm{Pb} / \mathrm{Pb}$ ages of $1761 \pm 6 \mathrm{Ma}$ and $1783 \pm 6$ $\mathrm{Ma}$, respectively, and a $\leq 1.78 \mathrm{Ga}$ intrusion age is possible.

Sample A2137 from the Kierovaara suite shows $\varepsilon_{\mathrm{Nd}}(2.0 \mathrm{Ga})$ of -4.2 and Simovaara monzonite sample (A2136) plots to a more positive evolution trend (Table 1 and Fig. 6). Secondary LREE depletion in sample A2135 has affected the Sm-Nd system and does not give the primary signal. Lu-Hf isotopic data (not shown) give similar $\varepsilon_{\mathrm{Hf}}$ values for samples A2135, A2137 and A2169, verifying the interpretation that secondary LREE fractionation has occurred. The $\mathrm{Sm}-\mathrm{Nd}$ modeling for LREE depletion gives ages at $0.3-0.7 \mathrm{Ga}$ between sample A2135, A2137 and A2169 (Figure 8), the ages of which are similar to $0.4-1.0 \mathrm{Ga}$ modeling ages for LREE depletion in eastern Finland (north ofT, inset in Fig. 1; Lahtinen et al., 2013). 
Figure 6. $\varepsilon_{\mathrm{Nd}}$ vs. age diagram for samples in this study (Table 1). Rovaniemi supersuite (Ro SS) trend is defined by felsic gneiss samples, which show a single cluster zircon ages (A1438, A1569, A1996, A2030; Lahtinen et al., 2015b). CHUR, Chondritic uniform reservoir. Depleted mantle evolution after DePaolo (1981).
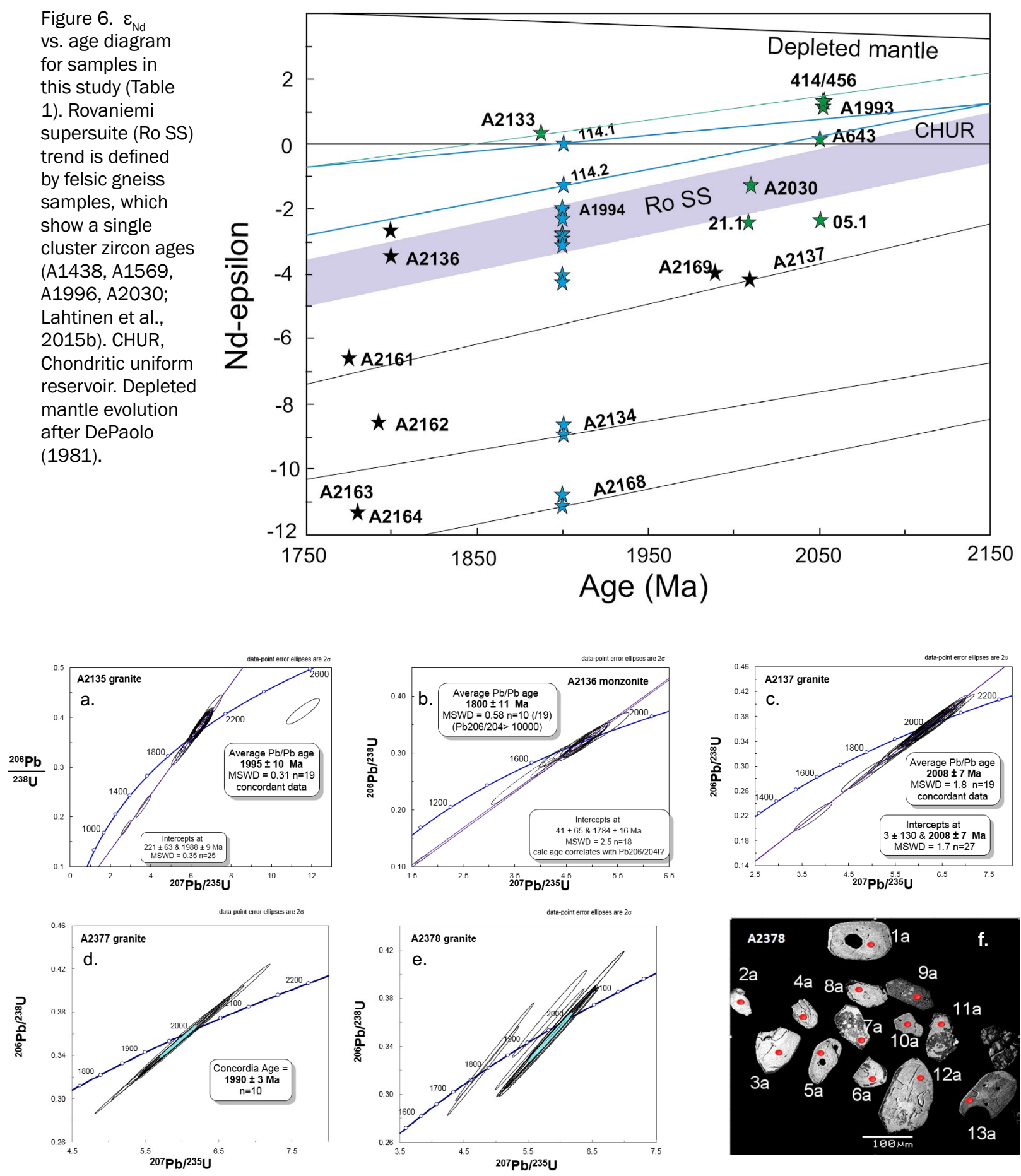

Figure 7. U-Pb Concordia diagrams for granite samples and SEM-image of zircons in sample A2378. 


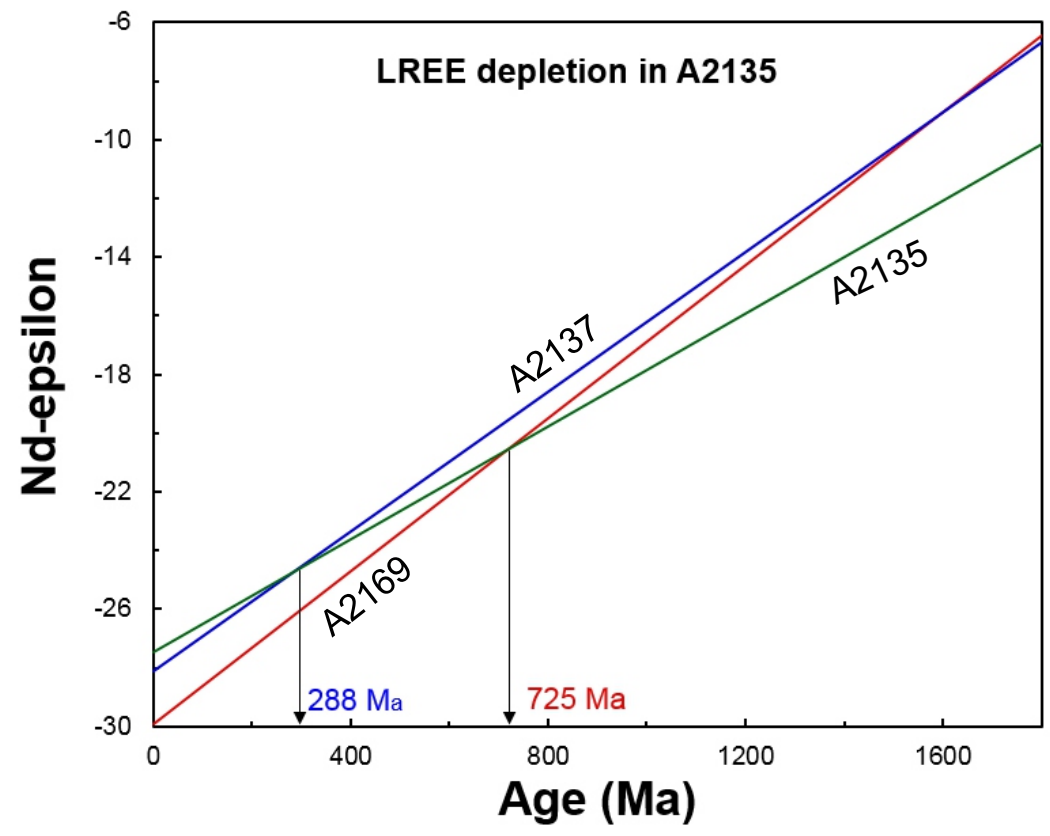

Figure 8. Sm-Nd isotope diagram showing data on the Kierovaara granites. Two-point age-calculations are shown for selected samples.

\section{Discussion}

\subsection{Provenance and depositional age of sedimentary rocks}

Selected geochemical features of the sedimentary rocks from the study area (Paskavaara, Mellajoki, Martimo, Hosiojoki and Uusivirka) are shown in Figs. 9 and 10. The Martimo suite sedimentary rocks have been further divided into the Liekopalo, Väystäjä and Kaskimaa units, and the Ristivuoma paraschists are considered separately from the other Uusivirka suite rocks. The Hosiojoki suite probably also includes rocks that are either volcanic or at least volcanoclastic in origin. Thus, two samples from site A2030 are also discussed in section 5.3.

Both the Paskavaara and Mellajoki suites show only Archean provenance based on detrital zircon ages and Sm-Nd data (Lahtinen et al., 2015b and Ranta et al., 2015), and a felsic source seems to dominate based on geochemical analyses. The more mafic garnet-mica paraschist A2165 from the Mellajoki suite also has an Archean Sm-Nd signature (Table 1) and does not favor the presence of a major mafic Paleoproterozoic component. The three samples from Liekopalo show a weathered source based on the Chemical Index of Alteration (CIA) values (Fig. 9c). The high proportion of 2.62.7 Ga detrital zircon ages in sample A2134 differ from the data obtained from the Mellajoki suite and Kivalo group by Ranta et al. (2015), which show the youngest peak at ca. 2.7 Ga. Sm-Nd data for sample A2134 (Fig. 6) also indicate a pure Archean source.

The Väystäjä metasedimentary rocks show a wide variation in geochemical composition (Fig. 9) also seen in two adjacent layers (samples 114.1 and 114.2) from outcrop RLL\$-2012-114. The geochemical differences do not follow the grain-size sorting trend and, e.g., La and Th values are extremely different (Electronic Appendix A; Fig. 9d). Sm-Nd data (Fig. 6) show trends that fit with samples from the Väystäjä volcanic unit. Unfortunately, no detrital zircon data are available, but as the Väystäjä metavolcanic rocks occur as interlayers (e.g., 05 in Fig. 2), it indicates a 2.05$2.1 \mathrm{Ga}$ depositional age for the unit. Two slightly different source components, one dominated by mafic volcanic source (low La and Th) and the other comprising more felsic crustal material, explain the geochemical variation. 

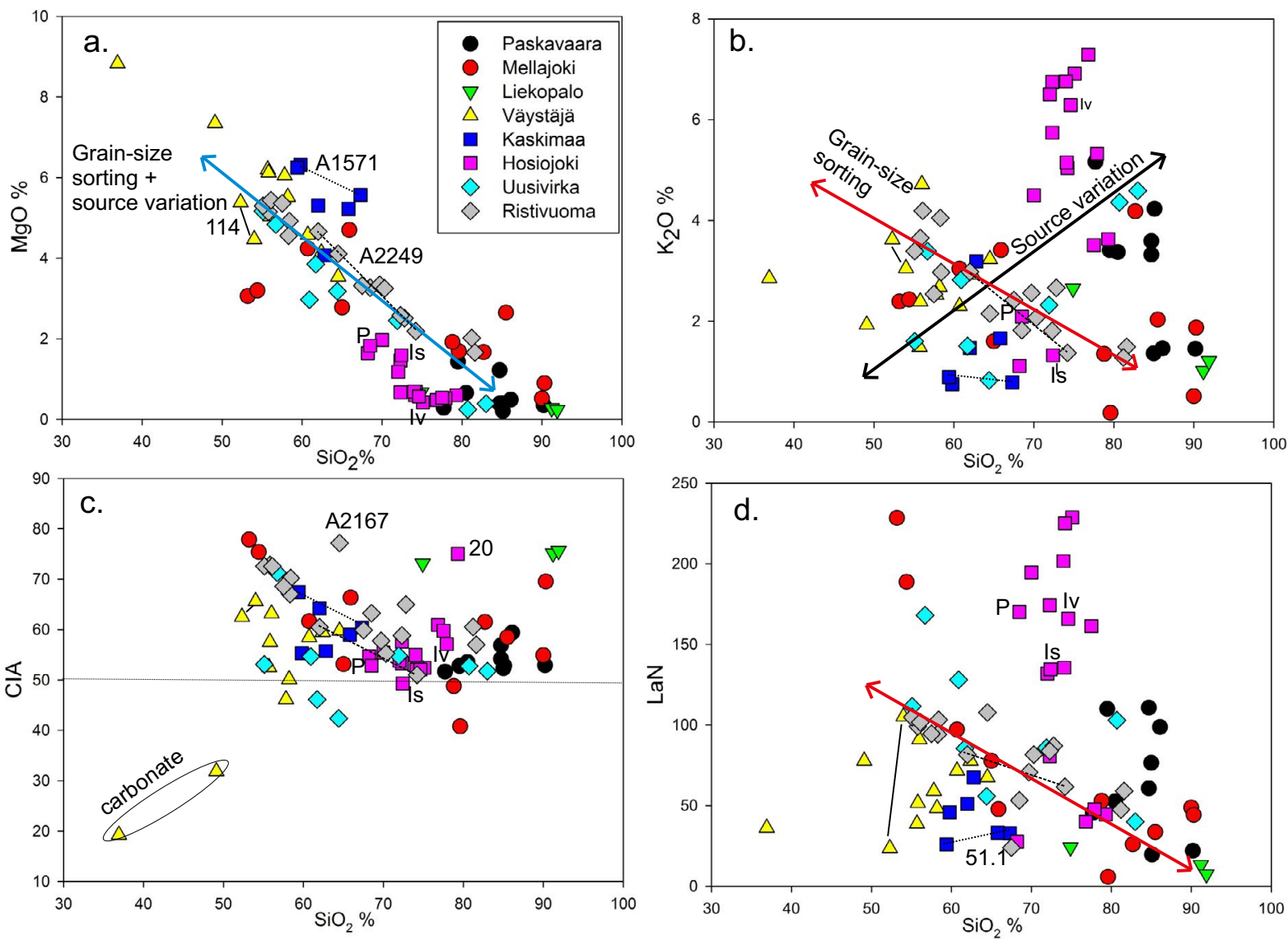

Figure 9. Harker-diagrams. Psammite-pelite pairs of samples 114, A1571 and A2249 are shown. Samples from the Hosiojoki suite include three other samples from the Rovaniemi supersuite; $P$ is a sedimentary paraschist $A 1570$ (Hanski et al., 2005) and Is (A1997) and Iv (RLL\$-2008-44.3) are from the same outcrop from the northern part of the CLGC (Fig. 1). Felsic gneiss Iv is chemically similar to A1996 (Electronic Appendix A), where all zircons are ca. 1.99 $\mathrm{Ga}$, whereas sample A1997 also contains older zircons in addition to a ca. 1.99 Ga population, indicating a clearer sedimentary origin (Lahtinen et al., 2015b).

The Kaskimaa turbidites are mafic in composition (e.g., high $\mathrm{MgO}$ in Fig. $9 \mathrm{a}$ and low $\mathrm{Th} / \mathrm{Sc}$ in Fig. 10b) characteristics of which have been used in delineating the Kaskimaa unit in Fig. 2. For the provenance of the Kaskimaa turbidites Lahtinen et al. (2015b) proposed a mixture of eolian quartz sands (rounded quartz clasts and zircon grains) from an Archean source (zircon ages), and weathered Paleoproterozoic $(\mathrm{Sm}-\mathrm{Nd})$ mafic volcanic rocks, based on geochemistry. One ca. 2.0 Ga old rounded zircon was found from sample A1571 but more data are needed to verify the presence of the 2.0 Ga zircon population.
The Hosiojoki suite is also variable in geochemical composition and samples do not follow the grain-size sorting trend (Fig. 9). They have typically a very felsic K-rich source enriched in $\mathrm{Nb}$ and Th (cf. Hanski et al., 2005) and $\mathrm{Nb} / \mathrm{Sc}$ ratio $>1$ seems to be a good discriminant (Fig. 10a). There is a trend towards a more typical crustal source component in the Hosiojoki samples that have mixed sources (e.g., P and Is in Figs. 9 and 10). Typically, Paleoproterozoic metasedimentary rocks in Finland lack 2.1-2.6 Ga detrital zircons (e.g., this study) but an unusual age cluster of 2.42.3 Ga and only few Archean zircons in sample Is 

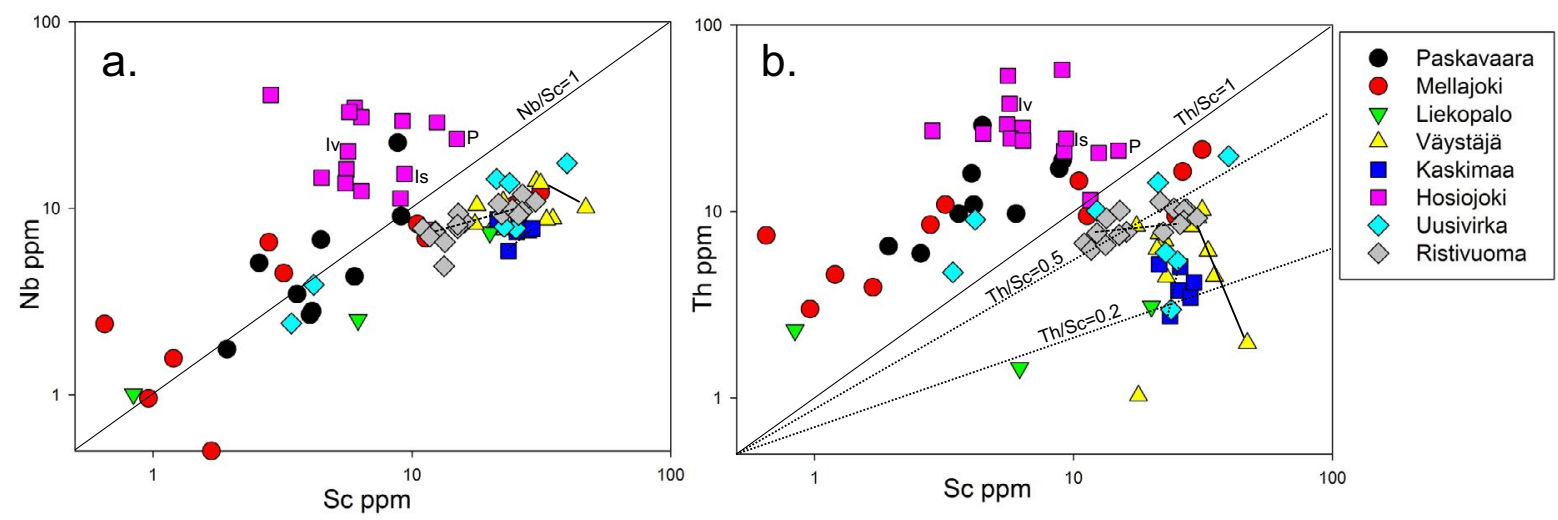

Figure 10. Plots of $\mathrm{Nb}$ and Th vs. Sc.

(A1997 in Fig. 1; Lahtinen et al., 2015b) indicate an anomalous crustal source in addition to the $\mathrm{K}-\mathrm{Nb}$-Th-rich source. The maximum depositional age for the Hosiojoki suite is 1.98-1.99 Ga and the dominant source is $\mathrm{K}$-rich felsic volcanic/hypabyssal source (directly or recycled) with an A-type affinity (see Hanski et al., 2005).

The Uusivirka metasedimentary rocks included in this study vary from hornblende-bearing metasedimentary rocks to metapelite and metaarkose. The Lylynmaanvaara hornblende-bearing psammite A1994 shows a most mafic source with $\mathrm{Th} / \mathrm{Sc}$ ratio of 0.22 (Fig. 10b). Obviously, a large geochemical variation (Figs. 9 and 10) favors multiple sources and probably different depositional settings for the samples. The maximum depositional ages of 1.92-1.91 Ga of these Uusivirka samples are slightly older than the 1.90-1.91 Ga ages of the Ristivuoma psammites. The Ristivuoma metasedimentary rocks show well-defined grain-size sorting trend (Figs. 9 and 10) indicating a mixed source, probably due to several sedimentary mixing stages. This well-mixed nature is seen in the very small decrease in the Th/ Sc ratio when going to more "mafic" pelites (higher Sc in Fig. 10b) and that A2449 psammite-phyllite pair have similar $\varepsilon_{\mathrm{Nd}}$ values (Table 1) apart from a large variation in $\mathrm{MgO}$ from $2.19 \%$ to $4.66 \%$, respectively (Electronic Appendix A).

\subsection{Mafic volcanic rocks}

Perttunen \& Hanski (2003) have shortly described the Väystäjä mafic tholeiitic basalts, comprising predominantly pillow lavas and some tuffs. The Väystäjä volcanic belt is ca. 2.09-2.05 Ga in age based on crosscutting dykes with an age of $2084 \pm 11$ $\mathrm{Ma}$ (Huhma et al., 2018) and an association of felsic porphyries (A643; $2050 \pm 8$ Ma; Perttunen \& Vaasjoki, 2001). Crustal contamination (increasing $\mathrm{Th} / \mathrm{Yb}$ ) is common in the Väystäjä mafic volcanic rocks but there is no indication of the presence of a subduction component based on the absence of a prominent $\mathrm{Nb}-\mathrm{Ta}$ minimum (Fig. 11a). Lithophile elements show large scatter indicating their mobile character but it is possible to divide the Väystäjä basalts into E-MORB and E-MORBOIB-type groups representing the lower and upper Väystäjä, respectively (Fig. 2). Sm-Nd data favor a strong crustal component in mafic volcanic rock RLL\$-2011-5.1, which is caused either by crustal contamination during magma ascent or mixing with sedimentary material. Sample N93001414 fits in the non-arc mantle array and has a positive $\varepsilon_{\mathrm{Nd}}$ value of +1.4 (Fig. $11 \mathrm{~b}$ and Table 1 ), which could be interpreted as the closest approximation of the mantle source. The non-arc geochemical signature and partly crustally contaminated composition of the Väystäjä basalts indicate a continental withinplate setting. 

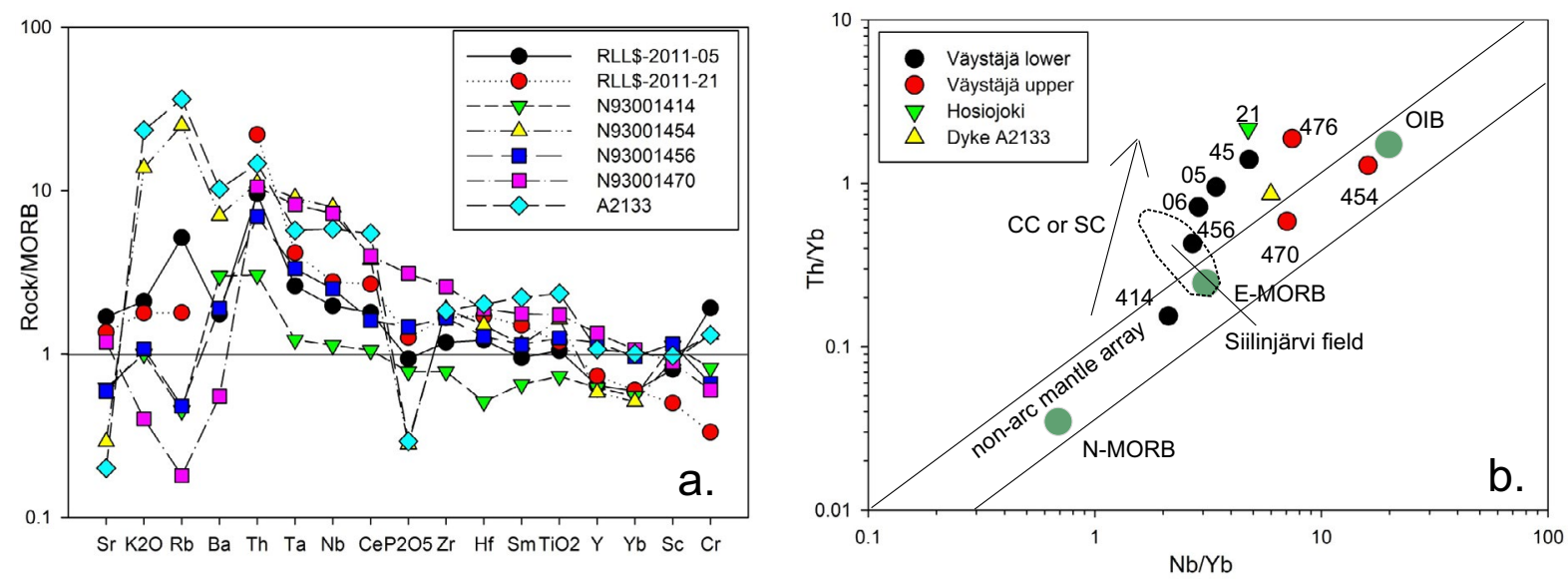

Figure 11. a. MORB-normalized (Pearce, 1983) element patterns and b. Th/Yb - Nb/Yb diagram for selected mafic volcanic samples of this study. Th/Yb vs. Nb/Yb diagram illustrates the input of Th either from crustal contamination (CC) or subduction-zone enrichment (SC). Diagram from Pearce (1983), Pearce and Peate (1995), and Stern et al. (1995). N-MORB, E-MORB, and OIB from Sun and McDonough (1989). Siilinjärvi basalt field after Lahtinen et al. (2015c).

Dyke A2133, having a comparable geochemical character to the more enriched upper Väystäjä basalts showing OIB-affinity (Fig. 11b), has an $\varepsilon_{\mathrm{Nd}}(1.88 \mathrm{Ga})$ value of +0.2 . The Hosiojoki mafic volcanic rock (RLL\$-2011-21 in Fig. 11a) shows a strong Th peak in the spidergram, which compared with $\varepsilon_{\mathrm{Nd}}(2.0 \mathrm{Ga})$ value of -2.4 , favors strong crustal contamination, most probably by an Archean crust.

The Siilinjärvi (Fig. 1 inset) bimodal volcanic association (ca. 2.06 Ga, Lukkarinen, 2008) is similar in age, composition and tectonic setting to the Väystäjä bimodal association. Felsic volcanic rocks in the Siilinjärvi area overlie within-plate type, crustally contaminated tholeiitic basalts, and alkaline basalts and non-contaminated tholeiitic basalts overlie both these rock units (Lukkarinen, 2008). The Siilinjärvi contaminated and noncontaminated tholeiitic basalts plot close to the lower Väystäjä rocks in Fig. 11b. Both tholeiitic and alkaline non-contaminated basalts have $\varepsilon_{\mathrm{Nd}}(2.06$ $\mathrm{Ga})$ values of ca. +2 and contaminated variants show $\varepsilon_{\mathrm{Nd}}(2.06 \mathrm{Ga})$ values down to -3.1 (Lukkarinen, 2008; Lahtinen et al., 2015c) which are comparable to those analyzed for Väystäjä (Fig. 6, Table 1). A similar continental within-plate rift setting and mantle source are likely for both suites.

\subsection{Felsic magmatism}

The oldest Paleoproterozoic felsic magmatic phase in the study area is the Väystäjä association of felsic porphyries (A643; $2050 \pm 8 \mathrm{Ma}$, Perttunen \& Vaasjoki, 2001) and volcano-sedimentary rocks (A1993, all zircons ca. 2.05 Ga Ma; Lahtinen et al., $2015 \mathrm{~b})$. The youngest rocks are the $1.78 \mathrm{Ga}$ granites (Ranta et al., 2015) and thus, we have a nearly $300 \mathrm{Ma}$ time span of felsic magmatism. Apart from the Martimo dyke and the Simovaara monzonites, it seems that the intermediate magmatic variants are lacking (Fig. 12a.b) and the felsic rocks represent either bimodal associations or melts derived from crustal melting. No age data for the Martimo dyke exist but based on crosscutting relations we correlate it to the ca. $1.88 \mathrm{Ga}$ Haaparanta (Haparanda) suite comprising both intermediate and felsic variants (e.g., Bergman et al., 2001). Few felsic samples derive from a sedimentary-dominated source, e.g. granite sample 93001413 with restitic micarich enclaves (Fig. 12a). The Hosiojoki quartz porphyry/felsic gneisses and Kierovaara granites are calc-alkaline whereas the Väystäjä volcanic rocks and the Simovaara monzonites are tholeiitic in 

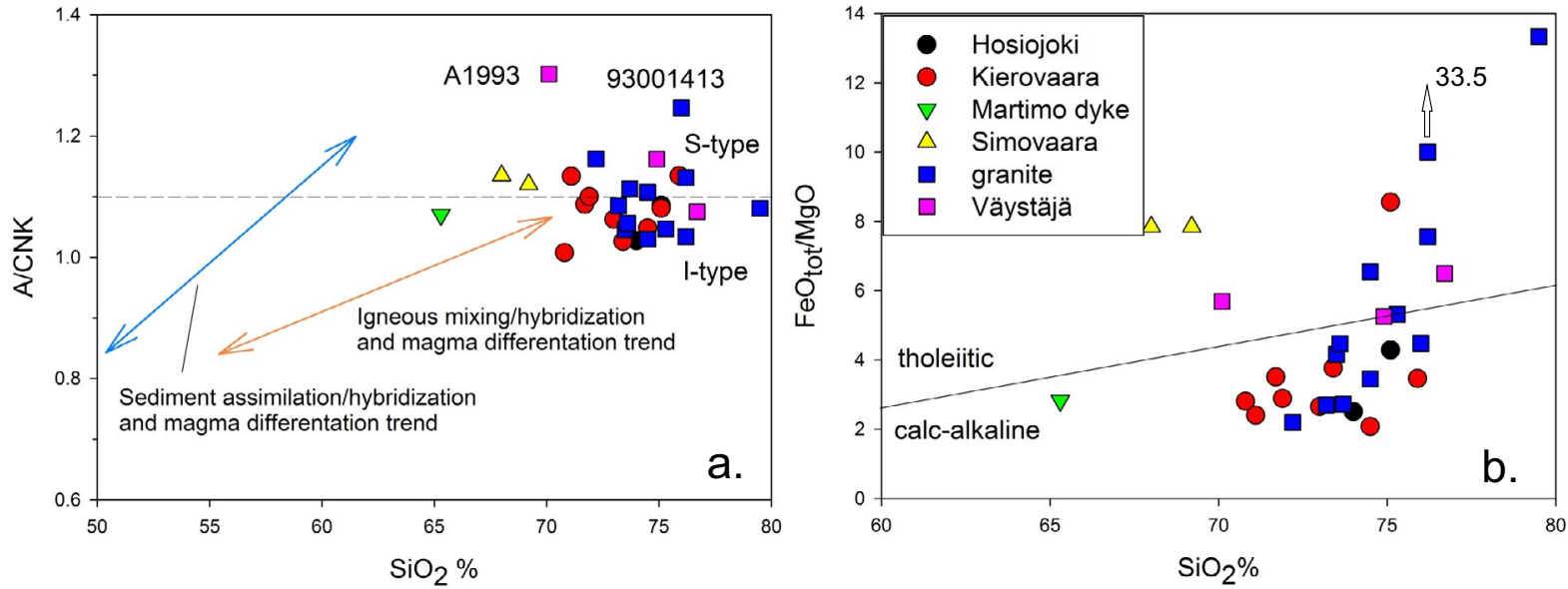

Figure 12. a. Aluminium saturation index and b. $\mathrm{FeO}_{\mathrm{tot}} / \mathrm{MgO}$ vs $\mathrm{SiO}_{2}$ diagrams for plutonic rocks in this study showing also inferred igneous and sediment assimilation trends in the ACNK diagram (Lahtinen et al., 2016). A/CNK is the molar ratio $\mathrm{Al}_{2} \mathrm{O}_{3} /\left(\mathrm{CaO}+\mathrm{K}_{2} \mathrm{O}+\mathrm{Na}_{2} \mathrm{O}\right)$ and $\mathrm{FeO}_{\text {tot }} / \mathrm{MgO}$ vs $\mathrm{SiO}_{2}$ diagram after Miyashiro (1974). Two samples $\mathrm{A} 2030$ and 93001509, which are from same outcrop (Electronic Appendix A), characterize the Hosiojoki suite.
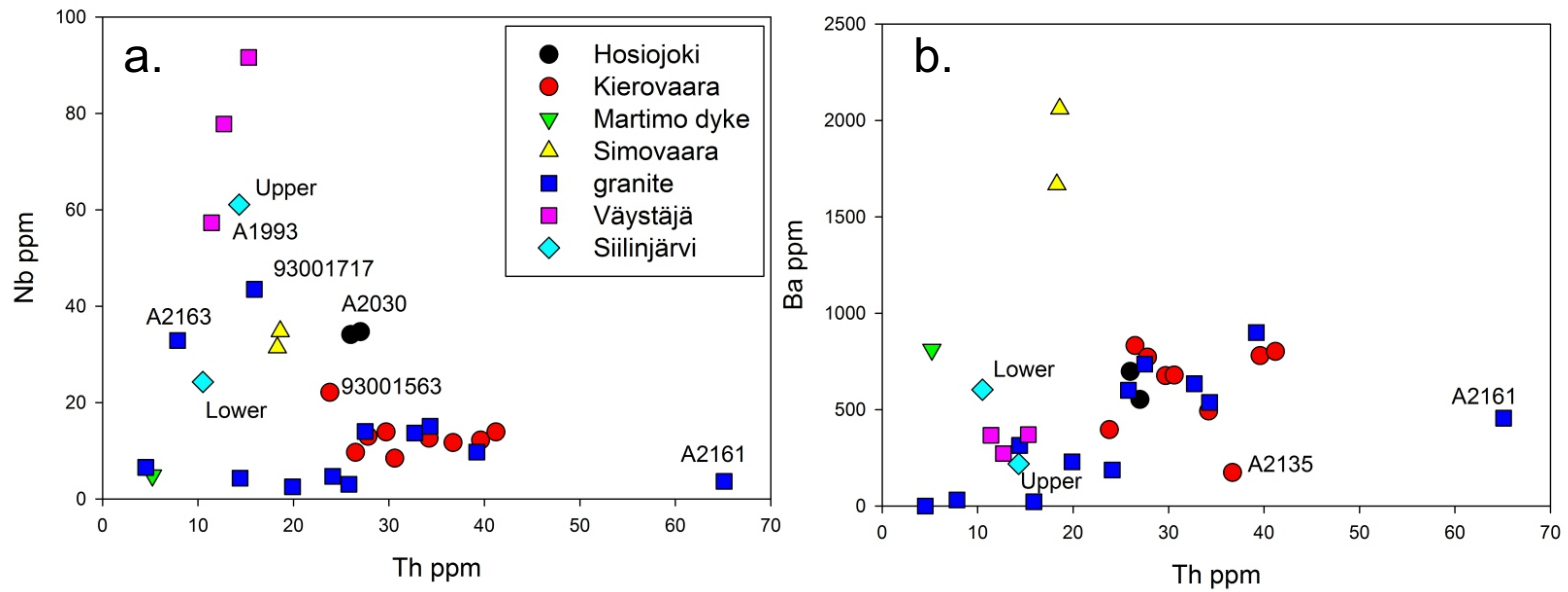

Figure 13. Plots of $\mathrm{Nb}$ and $\mathrm{Ba}$ vs. Th for the felsic rocks in this study.

character. The undefined granites vary from calcalkaline to tholeiitic in geochemical composition.

The felsic rocks in Väystäjä have similarities with the Siilinjärvi felsic tuffs, especially with the sample from the upper Kirjoniemi tuffs (Figs. 13 and 14$)$. The $\varepsilon_{\mathrm{Nd}}(2.06 \mathrm{Ga})$ value of -0.8 from the upper Kirjoniemi felsic tuff (Lukkarinen, 2008; Lahtinen et al., 2015c) is comparable with sample A643 from Väystäjä (Fig. 6 and Table 1). The lower Kirjoniemi felsic tuff with the $\varepsilon_{\mathrm{Nd}}(2.06 \mathrm{Ga})$ value of -4.8 and $\mathrm{T}_{\mathrm{DM}}$ of $2849 \mathrm{Ma}$ is characterized by a large
Archean crustal source component. Felsic samples from both areas plot in the within-plate granite fields in Figs. 14a,b. It seems that variable crustal contamination by Archean crust has affected these 2.05-2.06 Ga felsic rocks, but the most primary felsic magmas have had a common source with the mafic EMORB-OIB-type magmas via either differentiation or melting.

The Hosiojoki suite quartz feldspar porphyry/ felsic gneisses also plot in the within-plate granite fields in Figs. 14a,b (cf. Hanski et al., 2005) with 

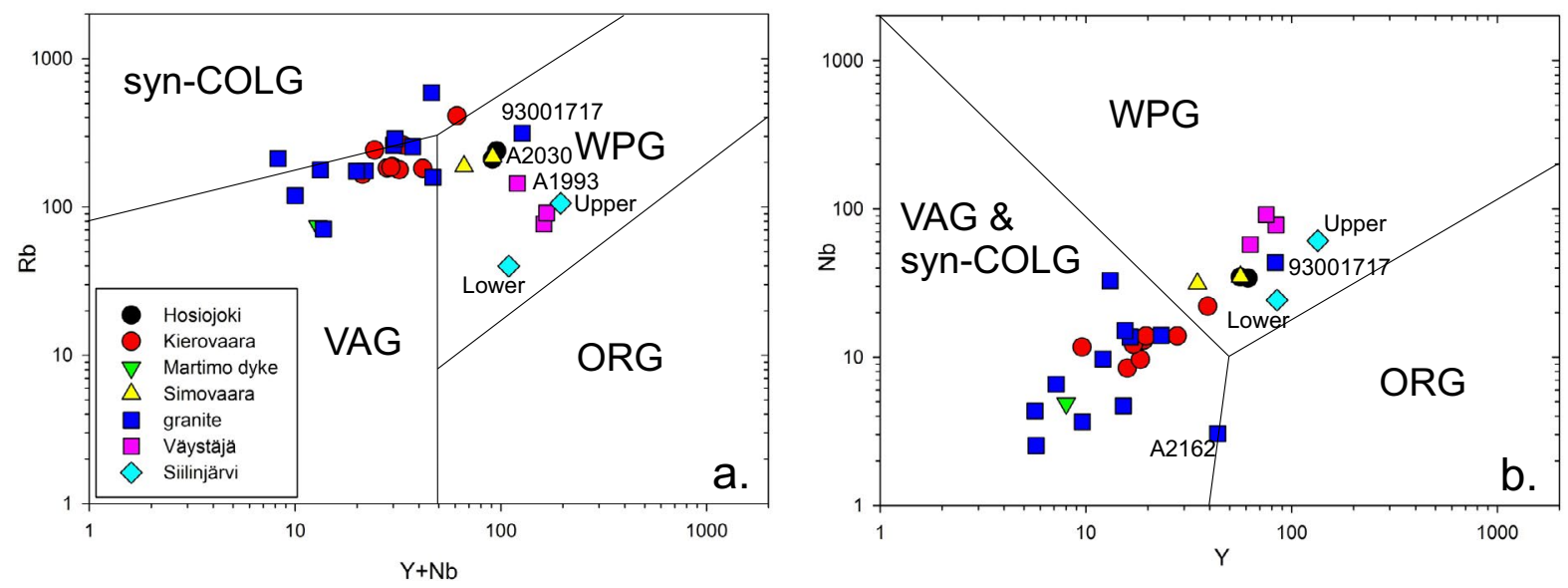

Figure 14. Granitoid discrimination diagrams (Pearce et al., 1984). WPG = within-plate granite; syn-COLG = syncollisional granite; $V A G=$ volcanic arc granite; $O R G=$ oceanic ridge granite. Upper and lower refer to the Siilinjärvi Kirjoniemi tuffs (Lukkarinen, 2008; Lahtinen et al., 2015c).

the Väystäjä felsic rocks but they have higher Th and $\mathrm{Rb}$ contents (Figs. 13 and 14 ) and a lower $\varepsilon_{\mathrm{Nd}}$ trend than samples from Väystäjä (Fig. 6). There is ca. 50-70 Ma age difference between the Väystäjä and Hosiojoki (or its precursor) felsic rocks. A possible scenario could be that the Väystäjä felsic rocks were derived from EMORB-OIB source and contaminated during ascent whereas the Hosiojoki suite derives from melting of a 2.1-2.05 Ga crustally contaminated an EMORB-OIB mafic rocks, which crystallized earlier in the lower crust. Both Väystäjä (A643) and Hosiojoki (A2030) samples have a deep negative Eu anomaly (Fig. 15) and low $\mathrm{Sr} / \mathrm{Y}$ (data in Electronic Appendix A) that favor large amounts of plagioclase in the source residue or strong feldspar fractionation. Low $\mathrm{Gd}_{\mathrm{N}} / \mathrm{Yb}_{\mathrm{N}}$ ratios (Fig. 15) indicate that garnet or orthopyroxene were not present and support a rather thin crust during melt formation. This would be obvious in the case of the Väystäjä felsic rocks, which occur with pillow lavas and sedimentary rocks. A rather thin crust during the formation of the Hosiojoki suite felsic rocks or their precursors is also indicated.

The granites of the Kierovaara suite are similar in age to the Hosiojoki suite at ca. 2.00-1.98 Ga. These suites are cogenetic but the geochemical (Figs. 2-15) and Sm-Nd isotopic (Fig.6, table 1) differences show that they cannot be comagmatic.
The Kierovaara granites are calc-alkaline and have a strong crustal component (high $\mathrm{Th} / \mathrm{Nb}$ in Fig. 13a), possibly due to a large amount of Archean source component (Fig. 6). The REE pattern (A2137 in Fig. 15) is rather similar to the Hosiojoki suite (A2030), but on a lower REE level. Their simultaneous occurrence but different origin could be explained by melting of different source materials during mafic magmatic underplating (Hosiojoki mafic rocks; Hanski et al., 2005). Some domains in lower crust have been dry during the melting of a dominantly 2.1-2.05 Ga contaminated mafic underplate, leading to A-type felsic rocks of the Hosiojoki suite. Other domains have been invaded by hydrous fluids, causing melting of both the 2.1-2.05 Ga contaminated mafic underplate and a refractory lower Archean crust and leading to the Kierovaara-type felsic magmatism. The fluids could have been derived from crystallization of mantlederived magmas in the lower crust.

The Martimo dyke is a calc-alkaline intermediate rock without a negative $\mathrm{Eu}$ anomaly (A2379 in Fig. 15). It has low $\mathrm{Nb}$ and $\mathrm{Th}$, high $\mathrm{Ba}$ contents, and it plots in the volcanic-arc granite fields (Figs. 12-14). The Simovaara monzonites are intermediate, tholeiitic rocks enriched in $\mathrm{Nb}$ and REE, and they plot in the within-plate granite fields (Figs. 12-15). The high Ba content 


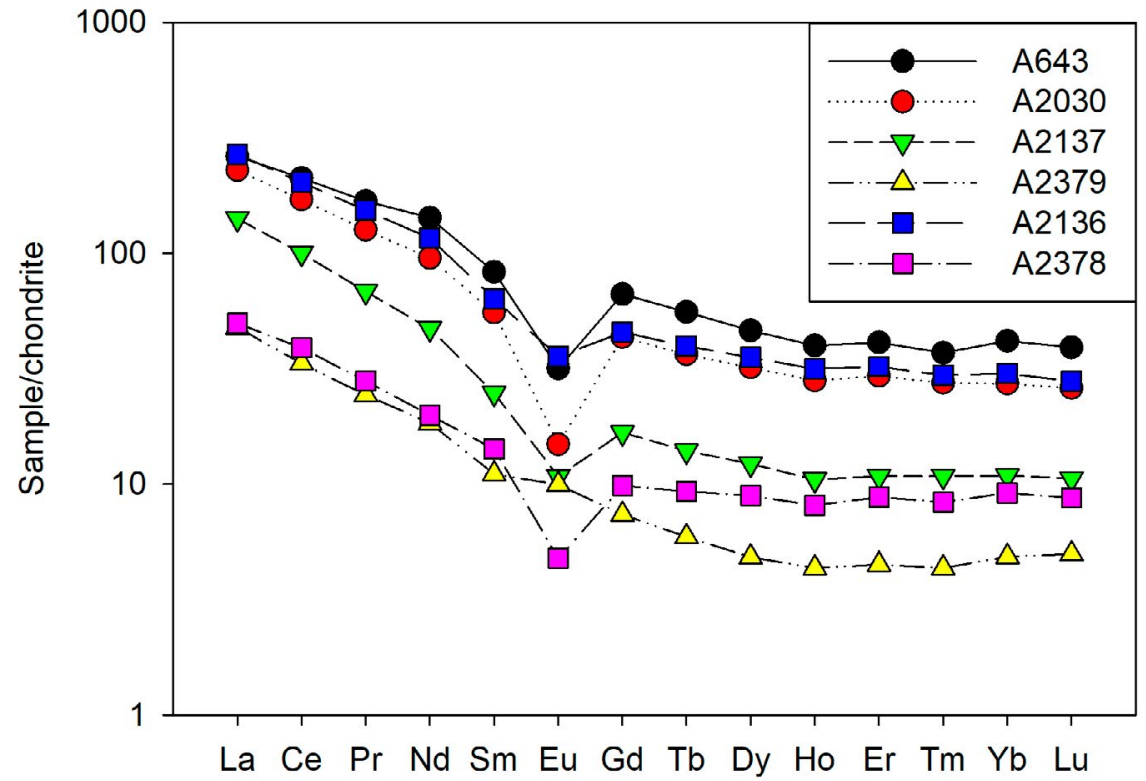

Figure 15. Chondritenormalized REE patterns for selected felsic rocks in this study. Normalizing values after Boynton (1984).

is a characteristic feature for the Simovaara monzonites. The age and geochemical composition of the Simovaara monzonites correlate with the intermediate differentiates of the ca. 1.79-1.80 $\mathrm{Ga}$ appinites. Appinites are post-collisional rocks possibly formed when large volumes of tholeiitic magma intruded in the lower crust and were selectively (e.g., Ba) contaminated with crustal rocks (Mutanen, 2011; Lauri \& Huhma, 2014; Tainio, 2014). Restite unmixing and incomplete magma mixing are characterized by the presence of enclaves whereas selective assimilation (dissolution, ion exchange), if complete, is seen only as chemical evidence of contamination without any original physical evidence (Clarke, 2007; Vásquez et al., 2009). We include the Simovaara monzonites into the Lohiniva appinite suite, which is present throughout the CLGC (Fig. 1; Bedrock of FinlandDigiKP).

The undefined granites are a heterogeneous group where some granites have been dated (A2161-A2164, Ranta et al., 2015), one has a possible age ( $\leq 1.78 \mathrm{Ga}$ for $\mathrm{A} 2378$, this study) and others are inferred to be $1.77-1.80 \mathrm{Ga}$ in age. Variable crustal origin, based on $\mathrm{Nb}-\mathrm{Th}$ and $\mathrm{Ba}-\mathrm{Th}$ variation, is proposed (Figs. 13a,b). Crustal source varies either from a pure Archean source, through melting of igneous crust or sediments derived from it, to a mixed source with additional Paleoproterozoic component (Fig. 6). A syn-collisonal tectonic setting is probable to most of these granites with some possible exceptions (e.g., 93001717 in Figs. 1 and 14). Some of these granites are pegmatitic and have very low REE (e.g., A2163 and A2164, Ranta et al., 2015). The occurrence of xenocrystic zircons in aplite granite A2378 (this study) and in pegmatitic granite dyke A2163 with a total lack of zircons in pegmatite granite A2164 (Ranta et al., 2015) favors the interpretation that these granites are rather low-temperature melts.

\subsection{Lithostratigraphic, lithodemic and tectonostratigraphic units}

Ranta et al. (2015) divided the study area (Fig. 2) into lithostratigraphic and lithodemic units. The Väystäjä, Korkiavaara (equals Hosiojoki) and Martimo were described as formations, and Mellajoki suite was kept as a lithodemic unit (cf. Perttunen \& Hanski, 2003). We have revised the area and divided it into lithodemic units following the classification used in the Bedrock of Finland-DigiKP database. 
Figure 16. Provisional lithodemic column of the Ylitornio nappe complex. Note the large breaks between some units (see text) due to structural breaks.

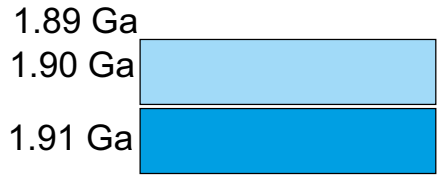

Ristivuoma paraschist, Uusivirka suite

Lylynmaanvaara paragneiss, Uusivirka suite

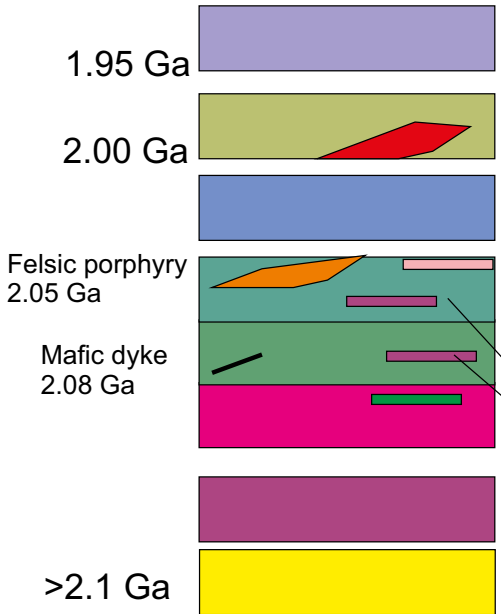

Karunki formation, Peräpohja belt

Hosiojoki suite + Kierovaara suite

Kaskimaa greywacke, Martimo suite

Dolomite

Upper Väystäjä mafic

Lower metavolcanic rock,

Martimo suite

Väystäjä paraschist, Martimo suite

Liekopalo paraschist, Martimo suite

Kivalo group and Mellajoki suite
The identified lithodemic units are shown in Fig. 16, but it should be noticed that the boundaries within each unit in Fig. 2 are partly inferred. Given the fact that the area is characterized by very low relief without any major vertical exposures, combined with thin-skin thrusting and common type-2 fold interference pattern (D1/D2; Lahtinen et al., 2015a; Sayab et al., 2017), makes that even outcrops nearby can derive from separate thrust sheets, and thus, belong to different lithodemic units.

We have little data on the Liekopalo graphitesulfide paraschists but interpretation based on aeromagnetic data indicates that these rocks partly acted as a detachment zone for the D1 thin-skin thrusting and the gradual change from quartzites to graphite-sulfide paraschists with quartzite beds (A2134 in Fig. 2) indicates that partly they are autochthonous-parautochthonous units closely associated with the quartzites. The Väystäjä mafic metavolcanic rocks are tentatively divided into the lower and upper volcanic rocks and the mafic metavolcanic rocks locally intercalate with the Väystäjä paraschists (05 in Fig. 2). The Kaskimaa turbiditic greywackes are interpreted to represent sedimentation in a deepening rift basin and they are younger than the Väystäjä rocks. The Väystäjä and Kaskimaa units are allochthonous as is also the Hosiojoki suite and the intruding Kierovaara suite granites. The Karunki formation (A720 in Fig. 1) is included in Fig. 16, as it shows a maximum depositional age of $1.95 \mathrm{Ga}$ (Lahtinen et al., 2015b) and is thus younger than Kaskimaa but older than rocks from the Uusivirka suite (including Ristivuoma).

The Uusivirka suite comprises sedimentary rocks that were deposited in early-, syn- or late-collisional settings (D1 of Lahtinen et al., 2015a) and deposited on older rocks both in the Norrbotten and Karelia provinces. The Uusivirka suite, excluding the Ristivuoma paraschists, shows variable composition following preferably source variation trends rather than grain-size sorting trends (Figs. 9 and 10) indicating poorly mixed and local sources. A good example is the Lylynmaanvaara paragneiss (A1994), which has hornblende as a major mineral, and shows mafic and non-weathered (low CIA; Chemical Index of 
Alteration) characteristics (Electronic Appendix A). The Ristivuoma paraschists have been separated as a lithodeme in the Uusivirka suite (Fig. 16). The Ristivuoma paraschists follow the grain-size sorting trends and show the typical increase of weathering clays (higher CIA) in the more pelitic samples (Figs. 9 and 10). All these features indicate moderate weathering, at least in one of the source components, and thorough mixing during multiple sedimentary processes. Noticeable is that no volcanic interlayers have been found so far from the Ristivuoma paraschists.

The structural elements in Fig. 2 are mainly from Lahtinen et al. (2015a) but the presence of D3 thrust planes are modified based on reinterpretation of the aeromagnetic data and additional field data. As discussed above, the Liekopalo parachists probably acted in places as the sole thrust surface during early stages of the east-vergent thrusting (D1). The D1 thrust stacks (nappes) in the Väystäjä mafic volcanic rocks, and the Hosiovaara-Kierovaara-Mellajoki suites have been thicker and easily detectable compared to the very thin stacking seen in the metasedimentary rocks of the Martimo suite (Fig. 2). This is due to the competence difference and the abundant occurrence of black shale horizons in the latter, which acted as glide planes, enhancing thin-skin type thrusting towards the east (Lahtinen et al., 2015a). D2 deformation is characterized by N-S shortening with the development of E-W trending F2 upright folds, which vary from very tight (e.g. an area close to sample A2249 in Fig. 2) to more open, seen in the Kierovaara and Mellajoki suites.

NE-SW shortening during D3 caused folding in the eastern part of the study area, and thrusting and reverse faulting in the western part (Fig. 2; see also Lahtinen et al., 2015a). NW-SE shortening caused local D4 folding (Fig. 2) and reverse faulting. The youngest stage (D5) caused SWside up reverse faulting in the western part of the study area (Figs. 2 and 4). As there are at least three stages of thrusting and reverse faulting and most of the thrust sheets or nappes are difficult to separate from each other, we classify the stacked area as the
Ylitornio nappe complex, which formed between $1.92 \mathrm{Ga}$ and $1.78 \mathrm{Ga}$. The Peräpohja Belt (Fig. 1) is outside our study area, but the early E-vergent shortening should have affected it to some degree. Our preliminary results indicate that this is the case, at least in some paraschist domains. The Peräpohja Belt dominantly comprises extremely competent quartzites, and thus the occurrence of very thick thrust sheets is probable. The use of lithostratigraphic classification is acceptable within each thrust sheet or inverted horsts and grabens, but their boundaries should be identified and separated as proper tectonostratigraphic units.

\subsection{Tectonic implications and correlations}

The tectonic evolution of the study area has been discussed in detail by Lahtinen et al. (2015a,b), and here we discuss it shortly, including some correlations outside the study area. A large-scale plume event initiated at $2.1 \mathrm{Ga}$ (Vuollo \& Huhma, 2005; Hanski \& Huhma, 2005), followed by continental breakup at $2.06 \mathrm{Ga}$ (Lahtinen et al., 2005). The ca. 2.06 Ga Siilinjärvi and 2.09-2.05 Ga Väystäjä bimodal volcanic complexes show crustally contaminated (Archean) and non-contaminated plume-derived magma types, and these units correlate well with each other. The occurrence of 2.1-2.05 Ga volcanic complexes in Tohmajärvi (Nykänen et al., 1994), Siilinjärvi (Lukkarinen, 2008), Kiiminki (Honkamo, 1989), Väystäjä and the Otanmäki alkaline granites (Kontinen et al., 2013) represent the "soft points" of a 'zigzag' rift pattern (100-150 km displacement, Fig. 1 inset) above small-scale convection cells (Gac \& Geoffroy, 2009), which formed during continent breakup (Lahtinen et al., 2015c). During this breakup a failed arm of a triple junction formed, seen today as the Central Lapland Granitoid Complex, a root of an aulacogen.

Deepening newly formed passive margin rift basins were the locus of deposition of thick turbidites (Kaskimaa greywacke). Renewed extension in the aulacogen produced the bimodal Rovaniemi 
Figure 17. Probability density plot for sedimentary rocks in selected areas. $\mathrm{PB}+\mathrm{TB}+\mathrm{HB}$ (Fig. 1 inset) data from Lahtinen et al. (2009, 2017); Viinijärvi suite data (samples A191, A676, A1172, A1631, A1632) from Lahtinen et al. (2010; including data from Huhma et al., 1991 and Claesson et al., 1993); Näläntöjärvi suite data (samples A1979, A1984, A1985, A1986) from Lahtinen et al. (2015c).

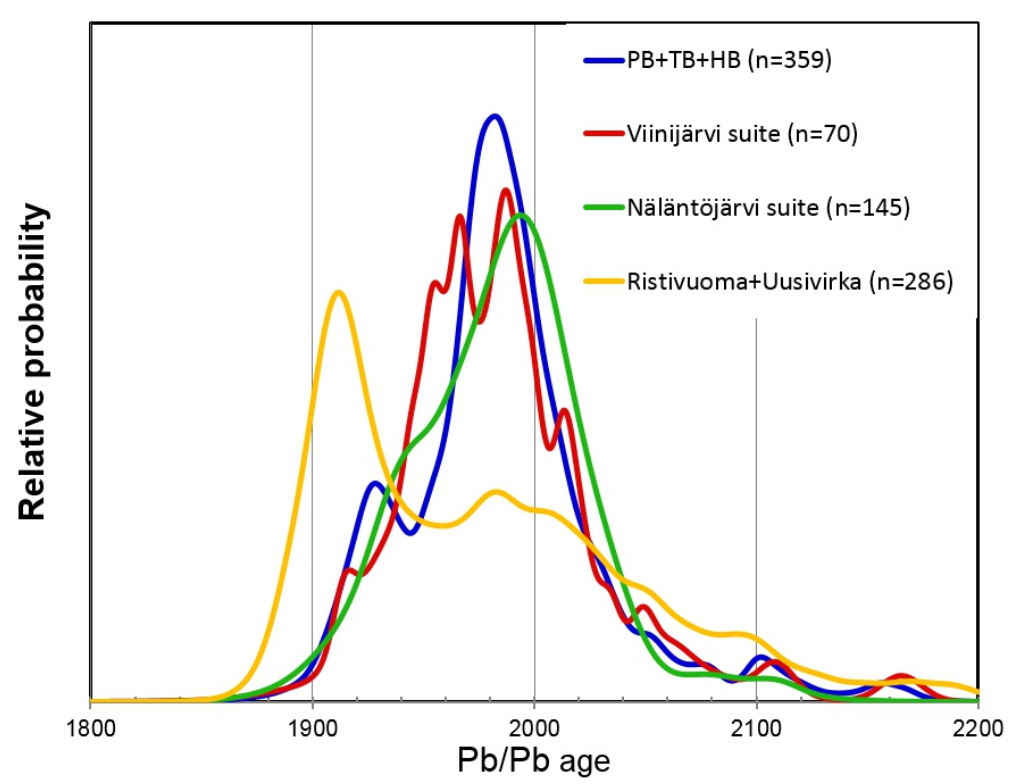

supersuite (Hosiojoki suite in Fig. 2) and the Kierovaara-type granites, which are confined to the aulacogen. The Rovaniemi supersuite is typically strongly recrystallized but shallow water to subarerial depositional setting seems possible (Hanski et al., 2005). This would favor an epeiric sea environment in the aulacogen.

Lately, a huge amount of detrital zircon age data have been acquired in Finland and wide correlations can be studied. In Fig. 17, the 1.9-2.2 Ga detrital zircons from the Ristivuoma and Uusivirka metasedimentary rocks (Fig. 5) are compared with the lower Svecofennian metasedimentary rocks, having $\geq 1.91 \mathrm{Ga}$ maximum depositional age (TB-Tampere Belt+PB-Pirkanmaa Belt+HB-Häme Belt, Lahtinen et al., 2017), and with the Viinijärvi and Näläntöjärvi suites of the Paleoproterozoic cover rocks of the Archean Karelia craton (Fig. 1 inset). The Viinijärvi and Näläntöjärvi suites are characterized by allochthonous deep-water turbidites with ophiolite-fragments and craton margin turbidites, respectively (Lahtinen et al., 2010, 2015c). All samples from the suites in Fig. 17 have variable amounts of Archean detrital zircons (15-50\%) but no clear trend has been noticed so far. Mixing of the Viinijärvi and Näläntöjärvi suites with a 1.92-1.93 Ga source could explain the Svecofennian $(\mathrm{TB}+\mathrm{PB}+\mathrm{HB})$ distribution pattern but variable $1.97-2.00 \mathrm{Ga}$ sources are probable (Lahtinen et al., 2009, 2017). A distribution pattern of the Uusivirka and Ristivuoma metasedimentary rocks is different and implies different source characteristics. There are Uusivirka samples (e.g., A1999 in Lahtinen et al., 2015b) which have a major component of $1.97-2.00 \mathrm{Ga}$ detrital zircons but this is not typical. All samples from the Ristivuoma paraschist are almost totally lacking detrital zircons of this age and are instead characterized by 1.90-1.94 Ga detrital zircons (Fig. 5; Electronic Appendix B).

Psammite A720 (Fig. 1) from the Karunki formation (Fig. 16) of the Peräpohja Belt has a maximum depositional age of $1.95 \mathrm{Ga}$ (Lahtinen et al., 2015b) and could be correlated with the craton cover sequences. Passive margin or early foredeep, during initial collision, origins are possible but more data are needed in order to describe the complete Karunki formation. The Uusivirka suite rocks have diverse sources, but probably represent foreland deposits from a rising orogen in the west (Lahtinen et al., 2015b). The older Uusivirka suite rocks, e.g. the Lylynmaanvaara paragneiss, are considered 
to be early collisional and derived from local sources whereas the younger Ristivuoma psammite-pelite associations are syn-collisional and derived from a recycled and thoroughly mixed source.

\section{Conclusions}

Based on the results of this study, the following conclusions can be drawn:

1. The Ylitornio study area comprises the Mellajoki, Martimo, Hosiojoki, Kierovaara and Uusivirka suites, which are part of a fold- and thrust belt and form the Ylitornio nappe complex. Although the main stacking has occurred between 1.92-1.89 Ga (D1 of Lahtinen et al., 2015a) later thrusting and reverse faulting have possibly continued until $1.78 \mathrm{Ga}$.

2. The Väystäjä bimodal volcanic rocks (2.09$2.05 \mathrm{Ga}$ ) are plume-related EMORB-OIB rocks that formed during continent breakup. Väystäjä and several other occurrences of ca. 2.1-2.05 Ga bimodal rocks along the present Karelia province margin represent the "soft points" of 'zigzag' rift pattern (100-150 km displacement) above small-scale convection cells.

3. The Kaskimaa greywacke with an inferred maximum depositional age of $2.1-2.0 \mathrm{Ga}$ is interpreted to represent sedimentation in a deepening rift basin following the breakup.

4. The coeval occurrence of the ca. 2.00$1.98 \mathrm{Ga}$ Hosiojoki A-type rocks and the Kierovaara-type granites is interpreted to represent dry melting of a dominantly 2.1 2.05 Ga contaminated mafic underplate, and hydrous melting of both the $2.1-2.05 \mathrm{Ga}$ contaminated mafic underplate and a refractory lower Archean crust, respectively.
These rocks are confined in the aulacogen, seen presently as the Central Lapland Granite Complex.

5. The Ristivuoma metasedimentary rocks are included in the Uusivirka suite. The Uusivirka suite comprises sedimentary rocks that were deposited in early-, syn- or late-collisional settings (D1 of Lahtinen et al., 2015b). The Uusivirka suite follows source variation trends rather than grain-size sorting trends, indicating poorly mixed and local sources. The Ristivuoma paraschists follow the grain-size sorting trends and show the typical increase of weathering clays (higher CIA) in the more pelitic samples. The older Uusivirka suite rocks, e.g. the Lylynmaanvaara paragneiss, are considered early-collisional (1.92-1.91 Ga) and derived from local sources whereas the younger Ristivuoma psammite-pelite associations are syn-collisional (1.91-1.90 Ga) and were derived from a recycled, thoroughly mixed source. These rocks were deformed during continued collision and development of the foreland fold and thrust belt.

\section{Acknowledgements}

We thank Leena Järvinen, Lasse Heikkinen, Jenni Keränen, Sari Lukkari, Yann Lahaye, Hugh O’Brien, Arto Pulkkinen, Mirja Saarinen and Pekka Simelius for their help in the laboratory. We are grateful to Markku Väisänen and an anonymous reviewer for their valuable comments on the manuscript.

\section{Supplementary data}

Electronic Appendices A-B for this article are available via Bulletin of the Geological Society of Finland web page. 


\section{References}

Bedrock of Finland - DigiKP. Digital map database [Electronic resource]. Espoo: Geological Survey of Finland [referred 01.01.2017]. Version 1.0.

Bergman, S., Kubler, L. \& Martinsson, O., 2001. Description of regional geological and geophysical maps of northern Norrbotten county (east of the Caledonian orogen). Sveriges geologiska undersökning, Ba 56, $110 \mathrm{p}$.

Berthelsen, A. \& Marker, M., 1986. 1.9-1.8 Ga old strike-slip megashears in the Baltic Shield, and their plate tectonic implications. Tectonophysics 128, 163-181. https://doi.org/10.1016/0040-1951(86)90219-2

Boynton, W.V., 1984. Cosmochemistry of the rare earth elements: meteorite studies. In: Henderson, P. (ed.), Rare Earth Element Geochemistry. Developments in Geochemistry, vol. 2. Elsevier, Amsterdam, pp. 63-114.

Claesson, S., Huhma, H., Kinny, P.D. \& Williams, I.S., 1993. Svecofennian detrital zircon ages - implications for the Precambrian evolution of the Baltic Shield. Precambrian Research 64, 109-130. https://doi.org/10.1016/0301-9268(93)90071-9

Clarke, D.B., 2007. Assimilation of xenocrysts in granitic magmas: principles, processes, proxies, and problems. Canadian Mineralogist 45, 5-30. https://doi.org/10.2113/gscanmin.45.1.5

Daly, J.S., Balagansky, V.V., Timmerman, M.J. \& Whitehouse, M.J., 2006. The Lapland-Kola orogen: Palaeoproterozoic collision and accretion of the northern Fennoscandian lithosphere. In: Gee, D.G. \& Stephenson, R.A. (eds.), European Lithosphere Dynamics. Geological Society, London, Memoirs 32, pp. 561-578. https://doi.org/10.1144/gsl.mem.2006.032.01.35

DePaolo, D.J., 1981. Neodymium isotopes in the Colorado Front Range and crust-mantle evolution in the Proterozoic. Nature 291, 684-687. https://doi.org/10.1038/291193a0

Gac, S. \& Geoffroy, L. 2009. 3D thermo-mechanical modeling of a stretched continental lithosphere containing lowviscosity anomalies (the soft-point theory of plate breakup). Tectonophysics $468,158-168$. https://doi.org/10.1016/j.tecto.2008.05.011

Hanski, E. \& Huhma, H., 2005. Central Lapland greenstone belt. In: Lehtinen, M., Nurmi, P.A. \& Rämö, O.T. (eds.), Precambrian Geology of Finland. Key to the Evolution of the Fennoscandian Shield. Elsevier Science B.V., Amsterdam, pp. 139-193. https://doi.org/10.1016/s0166-2635(05)80005-2

Hanski, E.J. \& Melezhik, V.A., 2012. Litho- and chronostratigraphy of the Karelian formations. In: Melezhik, V.A., Prave, A.R., Hanski, E.J., Fallick, A.E., Lepland, A.,Kump, L.R. \& Strauss, H. (eds.), Reading the Archive of Earth's Oxygenation. Volume 1: The Palaeoproterozoic of Fennoscandia as Context for the Fennoscandian Arctic
Russia - Drilling Early Earth Project. Springer-Verlag, Berlin/Heidelberg, pp. 39-110. https://doi.org/10.1007/978-3-642-29682-6_4

Hanski, E., Huhma, H. \& Perttunen, V., 2005. SIMS U-Pb, $\mathrm{Sm}-\mathrm{Nd}$ isotope and geochemical study of an arkositeamphibolite suite, Peräpohja Schist Belt: evidence for ca. $1.98 \mathrm{Ga}$ A-type felsic magmatism in northern Finland. Geological Society Finland, Bulletin 77, 5-29. https://doi.org/10.17741/bgsf/77.1.001

Hölttä, P. \& Heilimo, E., 2017. Metamorphic map of Finland. Geological Survey of Finland, Special Paper 60, 77-128.

Honkamo, M., 1989. Pohjois-Pohjanmaan vulkaniitit. Summary: Volcanic rocks in northern Ostrobothnia. Geological Survey of Finland, Report Investigation 89, 46 p.

Huhma, H., Claesson, S., Kinny, P.D. \& Williams, I.S., 1991. The growth of Early Proterozoiccrust: new evidence from Svecofennian zircons. Terra Nova 3, 175-179. https://doi.org/10.1111/j.1365-3121.1991.tb00870.x

Huhma, H., Mänttäri, I., Peltonen, P., Kontinen, A., Halkoaho, T., Hanski, E., Hokkanen, T., Hölttä, P., Juopperi, H., Konnunaho, J., Layahe, Y., Luukkonen. E., Pietikäinen. K., Pulkkinen, A., Sorjonen-Ward, P., Vaasjoki, M. \& Whitehouse, M., 2012. The age of the Archaean greenstone belts in Finland. In: Hölttä P. (ed.), The Archaean of the Karelia Province in Finland. Geological Survey of Finland, Special Paper 54, pp. 74-175.

Huhma, H., Hanski, E., Kontinen, A., Vuollo, J., Mänttäri, I. \& Lahaye, Y., 2018. Sm-Nd and U-Pb isotope geochemistry of the Palaeoproterozoic mafic magmatism in eastern and northern Finland. Geological Survey of Finland, Bulletin 405, 150p.

Iljina, M. \& Hanski, E.H., 2005. Layered mafic intrusions of the Tornio-Näränkävaara belt. In: Lehtinen, M., Nurmi, P.A. \& Rämö, O.T. (eds.), Precambrian Geology of Finland. Key to the Evolution of the Fennoscandian Shield. Elsevier Science B.V., Amsterdam, pp.101-138. https://doi.org/10.1016/s0166-2635(05)80004-0

Karhu, J.A., 2005. Paleoproterozoic carbon isotope excursion. In: Lehtinen, M., Nurmi, P.A. \& Rämö, O.T. (eds.), Precambrian Geology of Finland. Key to the Evolution of the Fennoscandian Shield. Elsevier Science B.V., Amsterdam, pp. 669-680. https://doi.org/10.1016/s0166-2635(05)80017-9

Kärki, A., Laajoki, K. \& Luukas, J., 1993. Major Palaeoproterozoic shear zones of the central Fennoscandian Shield. Precambrian Research 64, 207-223. https://doi.org/10.1016/0301-9268(93)90077-f

Kontinen, A., Huhma, H., Lahaye, Y. \& O’Brien, H., 2013. New U-Pb zircon age, $\mathrm{Sm}-\mathrm{Nd}$ isotope and geochemical data for Otanmäki suite granites in the Kainuu area, Central Finland. Geological Survey of Finland, Report of Investigation 198, 65-69. 
Kyläkoski, M., Hanski, E. \& Huhma, H., 2012. The Petäjäskoski Formation, a new lithostratigraphic unit in the Paleoproterozoic Peräpohja Belt, northern Finland. Geological Society of Finland, Bulletin 84, 85-120. https://doi.org/10.17741/bgsf/84.2.001

Laajoki, K., 2005. Karelian supracrustal rocks. In: Lehtinen, M., Nurmi, P.A. \& Rämö, O.T. (eds.), Precambrian geology of Finland - Key to the evolution of the Fennoscandian shield. Elsevier B. V., Amsterdam, pp. 279-342. https://doi.org/10.1016/s0166-2635(05)80008-8

Lahtinen, R. \& Huhma, H., 1997. Isotopic and geochemical constraints on the evolution of the $1.93-1.79 \mathrm{Ga}$ Svecofennian crust and mantle. Precambrian Research 82, 13-34. https://doi.org/10.1016/s0301-9268(96)00062-9

Lahtinen, R., Korja, A. \& Nironen, M., 2005. Palaeoproterozoic tectonic evolution of the Fennoscandian Shield. In: Lehtinen, M., Nurmi, P. \& Rämö, T. (eds.), The Precambrian Bedrock of Finland - Key to the evolution of the Fennoscandian Shield. Elsevier Science B.V,pp. 418-532. https://doi.org/10.1016/s0166-2635(05)80012-x

Lahtinen, R., Korja, A., Nironen, M. \& Heikkinen, P., 2009. Palaeoproterozoic accretionary processes in Fennoscandia. In: Cawood, P.A. \& Kröner, A. (eds.), Earth Accretionary Systems in Space and Time. The Geological Society, London, Special Publication 318, pp. 237-256. https://doi.org/10.1144/sp318.8

Lahtinen, R., Huhma, H., Kontinen, A., Kohonen, J. \& Sorjonen-Ward, P., 2010. New constraints for the source characteristics, deposition and age of the 2.1-1.9 Ga metasedimentary cover at the western margin of the Karelian Province. Precambrian Research 176, 77-93. https://doi.org/10.1016/j.precamres.2009.10.001

Lahtinen, R., Huhma, H., Lahaye, Y., Kontinen, A., Kohonen, J. \& Johanson, B., 2013. Long-lived LREE mobility in the cratonic, rift and foredeep to foreland sedi-mentary cover at the western margin of the Karelia Province. Lithos 175-176, 86-103. https://doi.org/10.1016/j.lithos.2013.05.003

Lahtinen, R., Sayab, M. \& Karell, F., 2015a. Near-orthogonal deformation successions in the poly-deformed Paleoproterozoic Martimo belt: Implications for the tectonic evolution of Northern Fennoscandia. Precambrian Research 270, 22-38.

https://doi.org/10.1016/j.precamres.2015.09.003

Lahtinen R, Huhma H., Lahaye Y., Jonsson E., Manninen T., Lauri L., Bergman S., Hellström F., Niiranen T. \& Nironen M., 2015b. New geochronological and SmNd constraints across the Pajala shear zone of northern Fennoscandia: reactivation of a Paleoproterozoic suture. Precambrian Research 256, 102-119.

https://doi.org/10.1016/j.precamres.2014.11.006
Lahtinen R, Huhma H., Lahaye Y., Kousa J. \& Luukas J., 2015c. Archean-Proterozoic collision boundary in central Fennoscandia: revisited. Precambrian Research 261, 127165. https://doi.org/10.1016/j.precamres.2015.02.012

Lahtinen R, Huhma H., Lahaye Y., Lode, S., Heinonen, S., Sayab, M. \& Whitehouse, M.J., 2016. Paleoproterozoic magmatism across the Archean-Proterozoic boundary in central Fennoscandia: Geochronology, geochemistry and isotopic data (Sm-Nd, Lu-Hf, O). Lithos 262, 507-525. https://doi.org/10.1016/j.lithos.2016.07.014

Lahtinen R, Huhma H., Sipilä, P. \& Vaarma, M., 2017. Geochemistry, $\mathrm{U}-\mathrm{Pb}$ geochronology and $\mathrm{Sm}-\mathrm{Nd}$ data from the Paleoproterozoic Western Finland supersuite - a key component in the coupled Bothnian oroclines. Precambrian Research 299, 264-281. https://doi.org/10.1016/j.precamres.2017.07.025

Lauri, L.S. \& Huhma, H., 2014. Age constraints for the appinites of the Central Lapland Granitoid Complex, Finland. Geological Survey of Finland, Report of Investigation 207, 90-93.

Lauri, L.S., Mikkola, P. \& Karinen, T., 2012. Early Paleoproterozoic felsic and mafic magmatism in the Karelian province of the Fennoscandian shield. Lithos 151, 74-82.

https://doi.org/10.1016/j.lithos.2012.01.013

Lehtonen, M., Airo, M.-L., Eilu, P., Hanski, E., Kortelainen, V., Lanne, E., Manninen, T., Rastas, P., Räsänen, J. \& Virransalo, P., 1998. Kittilän vihreäkivialueen geologia. Lapin vulkaniittiprojektin raportti. Summary: The stratigraphy, petrology and geochemistry of the Kittilä greenstone area, northern Finland. A report of the Lapland Volcanite Project. Geological Survey Finland, Report Investigation 140, 1-144.

Ludwig, K.R., 2003. Isoplot/Ex 3. A Geochronological Toolkit for Microsoft Excel. Berkeley Geochronologicy Center, Special Publication No. 4.

Lukkarinen, H., 2008. Siilinjärven ja Kuopion kartta-alueiden kallioperä [Electronic resource]. Summary: PreQuaternary rocks of the Siilinjärvi and Kuopio mapsheet areas. Suomen geologinen kartta 1:100 000 : kallioperäkarttojen selitykset lehdet 3331 ja 3242 . Espoo: Geologian tutkimuskeskus. 228 p. +2 app. maps. Electronic publication.

Meriläinen, K., 1980. Stratigraphy of the Precambrian in Finland. GFF 102, 177-180. https://doi.org/10.1080/11035898009450897

Miyashiro, A., 1974. Volcanic rock series in island arcs and active continental margins. American Journal of Science 274, 321-355.

https://doi.org/10.2475/ajs.274.4.321

Molnár, F., Oduro, H., Cook, N.D.J., Pohjolainen, E., Takács, Á., O’Brien, H., Pakkanen, L., Johanson, B. \& Wirth, R., 2016. Association of gold with uraninite and pyrobitumen in the metavolcanic rock hosted 
hydrothermal Au-U mineralisation at Rompas, Peräpohja Schist Belt, northern Finland. Mineralium Deposita 51, 681-702.

https://doi.org/10.1007/s00126-015-0636-6

Mutanen, T., 2011. Alkalikiviä ja appiniiteja. GTK unpublished report (in Finnish), 623 p.

Mutanen, T. \& Huhma, H., 2003. The 3.5 Ga Siurua trondhjemite gneiss in the Archaean Pudasjarvi granulite belt, northern Finland. Bulletin of the Geological Society of Finland 75, 51-68.

https://doi.org/10.17741/bgsf/75.1-2.004

Nironen, M., (ed.), 2017. Bedrock of Finland at the scale 1:1 000000 - Major stratigraphic units, metamorphism and tectonic evolution. Geological Survey of Finland, Special Paper 60, 128 p.

Nykänen, V.M., Vuollo, J.I., Liipo, J.P. \& Piirainen, T.A., 1994. Transitional $(2.1 \mathrm{Ga})$ Fe-tholeiitic-tholeiitic magmatism in the Fennoscandian Shield signifying lithospheric thinning during Palaeoproterozoic extensional tectonics. Precambrian Research 70, 45-65. https://doi.org/10.1016/0301-9268(94)90020-5

Ojakangas, R.W., Marmo, J.S. \& Heiskanen, K.I., 2001. Basin evolution of the Paleoproterozoic Karelian Supergroup of the Fennoscandian (Baltic) Shield. Sedimentary Geology 141-142, 255-285. https://doi.org/10.1016/s0037-0738(01)00079-3

Pearce, J.A., 1983. Role of the sub-continental lithosphere in magma genesis at active continental margins. In Hawkesworth, C.J. \& Norry, M.J. (eds.), Continental basalts and mantle xenoliths. Shiva, Natwich, pp. 230249.

Pearce, J.A. \& Peate, D.W., 1995. Tectonic implications of the composition of volcanic arc magmas. Annual Review Earth Planet Sciences 23, 251-285. https://doi.org/10.1146/annurev.ea.23.050195.001343

Pearce, J.A., Harris, N.B.W. \& Tindle, A.G., 1984. Trace element discrimination diagrams for the tectonic interpretation of granitic rocks. Journal of Petrology 25, 956-983.

https://doi.org/10.1093/petrology/25.4.956

Perttunen, V., 1985. On the Proterozoic stratigraphy and exogenic evolution of the Peräpohja area, Finland. Geological Survey of Finland, Bulletin 331, 131-141.

Perttunen, V. \& Hanski, E., 2003. Törmäsjärven ja Koivun kartta-alueiden kallioperä. Summary: Pre-Quaternary rocks of the Törmäsjärvi and Koivu map-sheet areas. Suomen geologinen kartta 1:100000 : kallioperäkarttojen selitykset lehdet 2631+2633. Espoo: Geologian tutkimuskeskus.

Perttunen, V. \& Vaasjoki, M., 2001. U-Pb geochronology of the Peräpohja Schist Belt, northwestern Finland. In: Radiometric age determinations from Finnish Lapland and their bearing on the timing of Precambrian volcanosedimentary sequences. Geological Survey of Finland, Special Paper 33, pp. 45-84.
Ranta, J-P., Lauri, L.S., Hanski, E., Huhma, H., Lahaye, Y. \& Vanhanen, E., 2015. U-Pb and Sm-Nd isotopic constraints on the evolution of the Paleoproterozoic Peräpohja Belt, northern Finland. Precambrian Research 266, 246-259. https://doi.org/10.1016/j.precamres.2015.05.018

Rasilainen, K., Lahtinen, R. \& Bornhorst, T.J., 2007. The Rock Geochemical Database of Finland Manual [Electronic resource]. Geological Survey of Finland. Report of Investigation 164. Espoo: Geologian tutkimuskeskus. 38 p. Electronic publication.

Sayab, M., 2009. Tectonic significance of structural successions preserved within low-strain pods: Implications for thinto thick-skinned tectonics vs. multiple near-orthogonal folding events in the Palaeo-Mesoproterozoic Mount Isa Inlier (NE Australia). Precambrian Research 175, 169186.

https://doi.org/10.1016/j.precamres.2009.09.007

Sayab, M., Miettinen, A., Aerden, D., \& Karell, F., 2017. Orthogonal switching of AMS axes during type- 2 fold interference: Insights from integrated X-ray computed tomography, AMS and 3D petrography. Journal of Structural Geology 103, 1-16. https://doi.org/10.1016/j.jsg.2017.09.002

Stern, R.A., Syme, E.C., Bailes, A. H. \& Lucas, S.B., 1995. Paleoproterozoic (1.90-1.86 Ga) arc volcanism in the Flin Flon Belt, Trans-Hudson Orogen, Canada. Contributions to Mineralogy and Petrology 119, 117141.

https://doi.org/10.1007/s004100050031

Strand, K., Köykkä, J. \& Kohonen, J. (eds.), 2010. Guidelines and Procedures for Naming Precambrian Geological Units in Finland. 2010 Edition Stratigraphic Commission of Finland: Precambrian Sub-Commission. Geological Survey of Finland, Guide 55, 41 p.

Sun, S.S. \& McDonough, W.F., 1989. Chemical and Isotopic Systematics of Oceanic Basalts: Implications for Mantle Composition and Processes. In: Saunders, A.D. \& Norry, M.J. (eds.), Magmatism in the Ocean Basins, Geological Society, London, Special Publications, 42, pp. 313-345. https://doi.org/10.1144/GSL.SP.1989.042.01.19

Tainio, J., 2014. Rovaniemen kunnassa sijaitsevien Vanttauksen, Lehmikarin ja Äijävaaran appiniitti-intruusioiden petrografian ja geokemian tutkimus. Unpubl. M.Sc. Thesis, Department of Geosciences and Geography, University of Helsinki, 93 p. (in Finnish)

Vanhanen, E., Cook, N.D.J., Hudson, M.T., Dahlenborg, L., Ranta, J.-P., Havela, T., Kinnunen, J., Molnár, F., Prave, A.R. \& Oliver, N.H.S., 2015. Rompas prospect, Peräpohja Schist Belt, Northern Finland. In: Maier, W.D., O’Brien, H. \& Lahtinen, R. (eds.), Mineral Deposits of Finland. Elsevier, Amsterdam, pp. 467-484. https://doi.org/10.1016/b978-0-12-410438-9.00018-2 
Vásquez, P., Glodny, J., Franz, G., Romer, R.L. \& Gerdes, A., 2009. Origin of fayalite granitoids: New insights from the Cobquecura Pluton, Chile, and its metapelitic xenoliths. Lithos 110, 181-198.

https://doi.org/10.1016/j.lithos.2009.01.001

Vecsey, L., Plomerová, J., Munzarová, H., Babuška, V. \& LAPNET working group, 2014. Velocity Images of the Lithosphere and Structure of Fennoscandian Upper Mantle. In: Eklund, O., Kukkonen, I.T., Skyttä, P., Sonck-Koota, P., Väisänen, M. \& Whipp, D., 2014 (eds.), Lithosphere 2014 - Eighth Symposium on the
Structure, Composition and Evolution of the Lithosphere in Finland. Programme and Extended Abstracts, Turku, Finland, November 4-6, 2014. Institute of Seismology, University of Helsinki, S-62, pp. 111-114.

Vuollo, J. \& Huhma, H., 2005. Paleoproterozoic mafic dikes in NE Finland. In: Lehtinen, M., Nurmi, P.A. \& Rämö, O.T. (eds.), Precambrian Geology of Finland: Key to the evolution of the Fennoscandian Shield. Developments in Precambrian Geology 14, pp. 195-236.

https://doi.org/10.1016/s0166-2635(05)80006-4 